\title{
Rebalancing the Spatial Economy: The Challenge for Regional Theory
}

\author{
Ron Martin \\ Professor of Economic Geography \\ Department of Geography, \\ University of Cambridge, \\ Downing Place, \\ Cambridge CB2 3EN \\ UK \\ Email: rlm1@cam.ac.uk
}

February 2015

Revised May 2015

\section{Acknowledgements}

This is a revised version of an Invited Opening Plenary Paper given at the Regional Studies Association Winter Conference on Sustainable Recovery? Rebalancing, Growth and the Space Economy London, 27-28 November, 2014. The invitation encouraged me to be provocative and to raise issues that might stimulate debate more widely across the conference. This I tried to do. To that end, the paper is deliberately discursive in nature, and is not intended to be a closely-argued piece of empirical analysis or theoretical exegesis, but rather retains the more open style in which it was originally delivered. I am grateful to the Regional Studies Association for the invitation to present the paper, and for the various responses I received from participants at and after that event. I also wish to thank Harry Garretsen (Groningen University), who looked particularly at my comments on the new spatial economics. In addition, two referees provided insightful comments which helped to sharpen the paper. To have responded to the issues they raised in detail would have required an even longer paper - indeed several papers! Of course, none of the above is responsible for the views expressed herein, which are mine alone, and, moreover, do not necessarily reflect those of the Regional Studies Association. 


\begin{abstract}
In response to the crisis of 2008 and deep recession that followed, the UK government assigned key importance to the need to 'spatially rebalance' the economy, to reduced its dependence on London and the South East by 'powering up' northern cities. This paper argues that the UK's problem of spatial economic imbalance is in fact a long-standing one, the very persistence of which raises key issues for our theories of regional development and policy. It argues that neither the new spatial economics, with its obsession with agglomeration, nor regional studies, with its plethora of concepts and paradigms but lack of integration and synthesis, offers a particularly convincing basis for devising policies capable of redressing the spatial imbalance in the UK's economic landscape.
\end{abstract}




\section{Introduction: The Concern over Spatial Economic Imbalance}

The year 2014 marked the $75^{\text {th }}$ anniversary of the first publication of August Lösch's classic work, The Economics of Location (1939; translated into English in 1954). Few read Lösch's book these days. If there is one classic author who has exercised a notable influence on economic geography, regional studies and spatial economics over recent years, it would of course be Alfred Marshall. Directly or indirectly, his comments on industrial districts and localisation economies have helped shape the growth over recent years of a voluminous literature on topics ranging from clusters, to local knowledge spillovers, to external economies, to agglomeration. By comparison, Lösch has received hardly any mention.

This is somewhat curious, since Marshall's main interests were not in economic geography or regional development: in fact, his discussions of industrial districts were far from central to his overall economic schema, and occupy only small sections of his work (Martin, 2006). Lösch, on the other hand, explicitly sought to provide an encompassing conceptual framework albeit a general equilibrium schema - for understanding the spatial economy, covering not just industrial location, but also trade, regional economic networks, cities, and certain financial aspects of the economic landscape, in particular geographical variations in interest rates, credit and consumer prices. ${ }^{1}$

No doubt it could be argued that Lösch's ideas and approach have long been superseded. After all, the disciplines of regional studies, regional science, regional economics, economic geography and urban economics have all moved on leaps and bounds, theoretically and empirically, since the time Lösch was writing, and economic circumstances now are much different from what pertained then. Nevertheless, his concluding statement surely continues to capture well what modern regional studies is (or should be) all about:

\footnotetext{
If everything occurred at the same time, there would be no development. If everything existed in the same place there could be no particularity. Only space makes possible the particular, which then unfolds in time. ... To let this space-conditioned particularity grow, without letting the whole run wild - that is political art (Epilogue: On Space, The Economics of Location, 1954 English edition, p. 508; emphasis in the original).
}

\footnotetext{
1 It was his intention to write a sequel to The Economics of Location, on money and the space economy, but alas he died prematurely before he could do so. He did write an extended essay on certain aspects of money, Theorie der Währung, which was published after his death, but to my knowledge this has never been translated into English.
} 
In fact, I suggest, this statement resonates closely with the circumstances we currently face in many advanced economies. For over the past two to three decades, a very particular model of economic growth has been pursued in many advanced nations that has indeed been allowed to 'run wild', culminating in the worst crisis since the early-1930s. This Neoliberal growth model, which took hold from the early-1980s onwards, founded on deregulation and privatization, and more recently also on cheap credit, was hailed as finally bringing an end to recessions and inflation, and ushering in what became labeled as the 'Great Moderation' in the US (Bernanke, 2004), and a new 'NICE' era (of non-inflationary continued expansion) in the UK. ${ }^{2}$ Above all, it was a model driven by a dramatic and seemingly unstoppable expansion of finance, banking, and household debt. Banks made record profits, the world's financial centres prospered, and many regions and cities, indeed whole nations, experienced rapid growth on the back of the booming housing and real estate markets that the banks were eager to fund and profit from. In the UK, the financial success of London was openly celebrated by the Labour Government at the time, and even held up as a model for the rest of the country to follow:

\begin{abstract}
I believe it will be said of this age, the first decades of the 21st century, that out of the greatest restructuring of the global economy, perhaps even greater than the industrial revolution, a new world order was created.... [M] ost importantly of all in the new world order, as the City [of London] bears witness, Britain's great natural resource are our people - resourceful, enterprising, innovative the foundation on which we will compete successfully.... The financial services sector in Britain, and the City of London at the centre of it, is a great example of a highly skilled, high value added, talent driven industry that shows how we can excel in a world of global competition. Britain needs more of the vigour, ingenuity and aspiration that you [London's financial class] already demonstrate is the hallmark of your success (Chancellor Gordon Brown, Mansion House Speech, June 20, 2007)
\end{abstract}

No sooner had this praise been lavished, however, than the economic boom on which it was based was brought to an abrupt halt. The financial crisis revealed the boom for what it was, a form of development that was highly unbalanced: on a global level, between creditor and debtor nations (especially China and the USA respectively); and within countries, between consumption and investment, between services and production, between state revenues and spending, between rich and poor, and, spatially, between different cities and regions. For while the long boom between the early-1990s and 2007 may have lifted most regions and cities, it lifted some much more than others.

\footnotetext{
2 The acronym NICE is usually attributed to the former Governor of the Bank of England, Mervyn King.
} 
Indeed in some instances, and the UK is a particularly prominent case, it reinforced regional inequalities. And in others, while it seemingly gave muchneeded momentum to lagging regions and cities, that momentum has since proved to be precarious, especially in the post-crisis era of fiscal austerity. And to compound matters, policy-makers in many countries appeared to assume that the boom in national growth would itself reduce spatial disparities in prosperity. In effect, politically, economic growth was allowed, in fact actively encouraged, to 'run wild' regardless of its spatial consequences. I wonder what Lösch would have made of all this.

Crises, of course, inevitably provoke a search for causes, and debate over remedies and alternative ways forward. The crisis, rightly, has thrown much of economics - especially mainstream economics - into disarray and disrepute. Reforms to the banking and financial system, though much trumpeted, have been slow, piecemeal and far from radical. Meanwhile, much of the Neoliberal project has remained unscathed. In fact, in some senses it has been reinforced. The new politics of austerity, of cutting public expenditure on a scale not seen since the interwar years, might be prosecuted under the banner of reducing public debt and imposing fiscal prudence, but it also resonates closely with the fundamental objective of Neoliberal ideology, of cutting back the state, and especially the welfare state (Konzelman, 2014).

Yet, at the same time, the crisis has evinced a new spatial awareness amongst policy-makers. From the World Bank, to the OECD, to the European Commission, to national governments, policy-makers have become more aware of economic geography, of the geographical foundations of national economic growth and development. In the UK, spatially unbalanced growth is now recognized politically both as having contributed to the economic crisis and also as a hindrance to future economic stability. A new mantra of 'rebalancing the economy' has been prosecuted as necessary to secure sustained recovery, and it is now acknowledged that the growth of the UK economy has been too dependent on a narrow range of activities - especially finance - and on one corner of the country, namely London and the Greater South East:

Our economy has become more and more unbalanced, with our fortunes hitched to a few industries in one corner of the country, while we let other sectors like manufacturing slide. Today our economy is heavily reliant on just a few industries and a few regions - particularly London and the South East. This really matters. An economy with such a narrow foundation for growth is fundamentally unstable and wasteful - because we are not making use of the talent out there in all parts of our United Kingdom. We are determined that should change. That doesn't mean picking winners, but it does mean 
supporting growing industries... And it doesn't mean ignoring London... but it does mean having a plan to breathe economic life into the towns and cities outside the M25 (David Cameron, UK Prime Minister, 28 May, 2010)

The UK government's initial response was to prosecute a new localism, a new 'local growth agenda' (H.M Government, 2010). Local Enterprise Partnerships (to replace the previous Regional Development Agencies) were established, together with a regional growth fund, local enterprise zones, city deals, and various other measures, all intended to promote local growth and greater spatial balance across the economy. And then, as the inevitable political warm-up began for the General Election in May 2015, both the UK Coalition Government and the Labour opposition suddenly discovered that important cities exist not just outside London, beyond the M25, but in the North of the country. From mid-2014 onwards, the Chancellor George Osborne began to talk of his offensive to promote what he called a 'northern powerhouse' to rival London in scale and dynamism:

\begin{abstract}
Something remarkable has happened to London over these recent decades. It has become a global capital, the home of international finance, attracting the young, the ambitious, the wealthy and the entrepreneurial from around the world in their tens of thousands. And it's a great strength for our country that it contains such a global city... But something remarkable has happened here in Manchester, and in Liverpool and Leeds and Newcastle and other northern cities over these last thirty years too. The once hollowed-out city centres are thriving again, with growing universities, iconic museums and cultural events, and huge improvements to the quality of life... The cities of the north are individually strong, but collectively not strong enough. The whole is less than the sum of its parts. So the powerhouse of London dominates more and more. And that's not healthy for our economy... We need a Northern Powerhouse too. Not one city, but a collection of northern cities - sufficiently close to each other that combined can take on the world (George Osborne, 2014)
\end{abstract}

However, as the above two quotes indicate, the UK Government has also been anxious that the growth of London is not hindered or compromised in any way. Herein lies a key conundrum: how to achieve a greater degree of 'spatial balance' in the economy whilst also wanting to protect and enhance the gains from spatial agglomeration of economic activity and growth in the already prosperous London-South East region. Much of the debate surrounding this issue has revolved around a stark question: "is London good or bad for the rest of the UK"? On the one side are those who point to the benefits of the Greater London economic machine in generating demand for goods and services in the rest of the UK, as a vital source of export earnings, and as a major contributor to the taxes needed to help fund welfare payments and public spending across the nation as a whole (see for example, City of London Corporation, 2011, 2014). But on the other side are those who see London as 
akin to a 'country apart', even a quasi-independent 'city-state', as a region which has become increasingly detached from the rest of the UK in terms of its level of prosperity, its economic growth, its global orientation, and its cyclical behaviour (Deutsche Bank, 2013). Some go further, and regard it as having become a sort of 'economic black hole', sucking in key human and financial resources from, and to the detriment of, the rest of the country. Indeed, as Vince Cable, as the Coalition Government's own Secretary of State for Business, Innovation and Skills opined:

One of the big problems that we have at the moment... is that London is becoming a kind of giant suction machine, draining the life out of the rest of the country (Cable, 2013).

A similar view was subsequently voiced by Scotland's First Minister:

London has a centrifugal pull on talent, investment and business from the rest of Europe and the world. That brings benefits to the broader UK economy. But as we know, that same centrifugal pull is felt by the rest of us across the UK, often to our detriment. The challenge for us all is how to balance this in our best interests - not by engaging in a race to the bottom, but by using our powers to create long-term comparative advantage and genuine economic value (Sturgen, 2014).

Certainly in the cities and regions outside London there is a widespread feeling that their conditions and needs are not taken into account or responded to by national politics and policymaking, much of which is highly London-centric (Wilcox, Nohrova and Bidgood, 2014).

Although arguments about the economic 'balance sheet' between London and the rest of the UK are hampered by a serious lack of data on the flows of trade and finance between the regions and cities of the country, the fact is, of course, that economic growth is not some simple 'spatial zero-sum game' (Martin, 2008; Gardiner, Martin and Tyler, 2010). There is not some fixed amount of economic growth or activity that has to be distributed across the national space economy. It is not a case of holding back prosperous areas like the London-Greater South East region in order to promote activity in the less prosperous cities and regions of the country. But it is a matter of ensuring that the less prosperous regions and cities are able to realize their full economic potential. To do this they need proper and fair access to the public and private resources necessary to gain 'second wind', to use Paul Krugman's (2005) graphic phrase. And this means that there is a need to examine whether and to what extent economic, financial and political power is too concentrated in London; whether the 'economic playing field', far from being level, is too tilted in London's favour. 
These issues have a salience far beyond the UK. Not dissimilar concerns and debates about spatial economic imbalance and disparity can be found across the European Union, in the United States, China, and elsewhere. The impact of the crisis in Europe, for example, has exposed major divisions between those member states inside the monetary union, and those outside; and within the Eurozone itself, between the stronger more central regions, especially in Germany, and weaker more peripheral regions, such as in Italy and Greece (Fingleton, Garretsen and Martin, 2014). In the absence of a strong centralized fiscal stabilisation mechanism, the existence of marked regional economic disparities across the Eurozone is a weak aspect of monetary union (see Martin, 2001), and compounds the problem of recovering from the recession that continues to afflict many of the Eurozone members. At the same time, many larger cities across Europe have seen a slowdown in relative growth (Dijkstra, Garcliazo and McCann, 2013), while in the USA the growth and development paths of cities appear to have become increasingly divergent (Markusen and Schrock, 2006; Hobor, 2013; Storper, 2013; Storper et al, 2014; Moretti, 2013). Spatial economic imbalances are a prominent feature of many countries, and in some cases have widened in recent years.

I want to argue in this paper that spatial economic imbalance in the UK, despite the Government's portrayal of it as a recent development, is but the latest manifestation of a long-standing and systemic feature of the British model of national political economy. As such it poses a fundamental problem, and its resolution presents a major challenge for both regional theory and regional policy. Just how should we theorise persistent spatially unbalanced growth, and what sort of policy response is called for? Is regional studies in a position to provide convincing answers to these sorts of questions? My worry is that it is not; or rather, that despite its impressive array of concepts, perspectives and ideas, it lacks both the integration and normative features necessary to provide a coherent and convincing framework capable of addressing the big questions relating to uneven regional growth and development. For these and other reasons, it has lost out to the 'new spatial economics' which seems to have captured much of the policy discourse surrounding the issue of spatial economic imbalance. ${ }^{3}$ But before addressing these worries in more detail, let me briefly examine the scale of imbalance in the UK, my empirical focus in this paper.

\footnotetext{
3 As will be discussed below, I use the term 'new spatial economics' to include the New Economic Geography (NEG) and the New Urban Economics (NUE).
} 


\section{Spatial Imbalance in the UK Economy: The Rediscovery of a Long-Standing Problem}

The fact of the matter is that the current issue of spatial imbalance in the UK economy is hardly new, but merely a rediscovery of a long-entrenched problem. Estimates by leading economic historians (see Lee, 1979; Crafts, 2005; Geary and Stark, 2012) reveal that even by the middle of the $19^{\text {th }} \mathrm{C}$, London had come to dominate the map of relative prosperity in the UK, by some margin (see Table 1). Over the remainder of the $19^{\text {th }} \mathrm{C}$ into the first decades of the $20^{\text {th }} \mathrm{C}$, regional economic disparities in Britain widened significantly, with London and the surrounding South East pulling further ahead from the rest of the country. The degree of imbalance was reinforced by the highly uneven regional impact of the economic upheavals and crises of the 1920s and 1930s. While the staple export industries that had formed the economic base of much of northern Britain in Victorian times were losing out

Table 1: Spatial Imbalance in the British Economy, 1871-2001:

Regional GDP per Capita Relative to the Great Britain Average (GB=100)

\begin{tabular}{|lrrrrrr|}
\hline GB=100 & $\mathbf{1 8 7 1}$ & $\mathbf{1 9 1 1}$ & $\mathbf{1 9 7 1}$ & $\mathbf{1 9 8 1}$ & $\mathbf{1 9 9 1}$ & $\mathbf{2 0 0 1}$ \\
London & 147.3 & 165.6 & 123.4 & 126.0 & 129.7 & 132.4 \\
South East & 88.5 & 124.6 & 104.6 & 108.4 & 117.1 & 123.5 \\
East Anglia & 97.0 & 76.8 & 92.8 & 94.7 & 113.7 & 117.9 \\
South West & 88.6 & 85.7 & 93.9 & 91.8 & 92.4 & 91.0 \\
East Midlands & 106.2 & 90.6 & 95.7 & 95.6 & 95.2 & 91.2 \\
West Midlands & 84.8 & 78.4 & 101.9 & 95.6 & 89.4 & 89.4 \\
Yorks-Humberside & 91.3 & 76.2 & 92.5 & 90.2 & 88.6 & 84.1 \\
North West & 106.0 & 97.2 & 95.3 & 92.9 & 90.5 & 89.6 \\
North & 94.1 & 89.5 & 86.1 & 92.2 & 90.6 & 78.9 \\
Wales & 87.7 & 90.1 & 87.5 & 82.0 & 84.1 & 78.2 \\
Scotland & 89.9 & 102.1 & 92.2 & 94.8 & 100.1 & 93.5 \\
Coefficient of Variation (\%) & $\mathbf{1 7 . 7}$ & $\mathbf{2 4 . 9}$ & $\mathbf{1 0 . 5}$ & $\mathbf{1 1 . 6}$ & $\mathbf{1 3 . 1}$ & $\mathbf{1 6 . 6}$ \\
\hline
\end{tabular}

Source of Data: Crafts (2005). Northern Ireland is omitted due to lack of consistent comparable historical data. The estimates for 1991 and 2001 have been adjusted from present regional boundaries to be comparable with the old standard regions. It should be noted that the estimates are derived mainly from individual tax returns, and hence are essentially residence based.

to more modern or cheaper international competition, the emergence of the new mass consumer goods growth industries of the period overwhelmingly benefited London and the South East: according to Scott (2007), for example, 
during the 1920s and 1930s London and the South East attracted no less than 75 percent of all new manufacturing establishments.

The resultant scale of spatial economic imbalance, and particularly the concentration of relative growth and prosperity in London, was highlighted in the famous Report of the Barlow Commission in 1940, in terms that were not a little controversial, and which resonate uncannily with the view expressed seventy five years later by Vince Cable referred to above:

The contribution in one area of such a large proportion of the national population as is contained in Greater London, and the attraction to the Metropolis of the best industrial, financial, commercial and general ability, represents a serious drain on the rest of the country (Barlow Commission, 1940, para. 171).

As Barlow saw it, there was a strong case for spatial rebalancing the British economy, and this required deliberate Government intervention. His arguments for redistributing economic activity away from London to the northern regions of the UK had a major influence on the regional policy model introduced after the War, and which held sway until the end of the 1970s. ${ }^{4}$ Over this period, from 1945 to the mid- to late-1970s, the scale of regional disparity in Britain, especially as between London and the rest of the country, declined somewhat. ${ }^{5}$ How far this was due to the impact of regional policy is an issue of some debate. But what is clear is that by the early-1970s, as the long post-war boom came to an end, the degree of regional economic imbalance across the UK had fallen (Table 1).

Since then, however, and particularly since the early-1990s, regional disparities have widened dramatically once again, as economic growth in London and the South East has outstripped that in the rest of the country (Figure 1 and Table 2; see also Martin, 2010; Gardiner, Martin and Tyler, 2013; Deutsche Bank, 2013). Taking the period since 1971, and using the UK Government Office regions which replaced the old Standard Regions in Table 1 , by 2011 a cumulative growth gap in GVA of nearly 40 percentage points had opened up between the southern and northern halves of the country

\footnotetext{
4 In essence, this policy model was a combination of restrictions on new and expanded factory development in the south east of the country (Industrial Development Certificates) combined with various capital grants for investments in premises and equipment made in the designated assisted areas of northern and peripheral UK.

5 Various estimates have been made of the numbers of new jobs created by regional policy in the depressed areas of the UK from the 1950s to the end of the 1970s. But producing such estimates is fraught with methodological problems, not least agreeing a meaningful counterfactual of what employment trends in these assisted regions would have been in the absence of policy.
} 
(Figure 2). This is the so-called 'North-South Divide'; and while this notion obviously obscures what at a local scale is inevitably a much more complex picture, the epithet is not without validity (Martin, 2004). ${ }^{6}$ Not only does this growing gap between 'North' and 'South' represent a significant permanent loss of output to the national economy, it has also meant lower incomes and employment opportunities in northern cities and regions themselves. The upshot is that together, London and the South East now make up almost 37 percent of the national economy (in terms of their share of GDP), compared to 26 percent in 1911. What is abundantly clear is that not only is the broad geographical imbalance in the UK economy a long-standing and persistence feature, it is now greater than at any time in the country's modern recorded

Figure 1: Divergent Regional Growth across the UK, 1990-2011 (Workplace Based Gross Value Added in Constant 2006 prices), Indexed to 1990=100

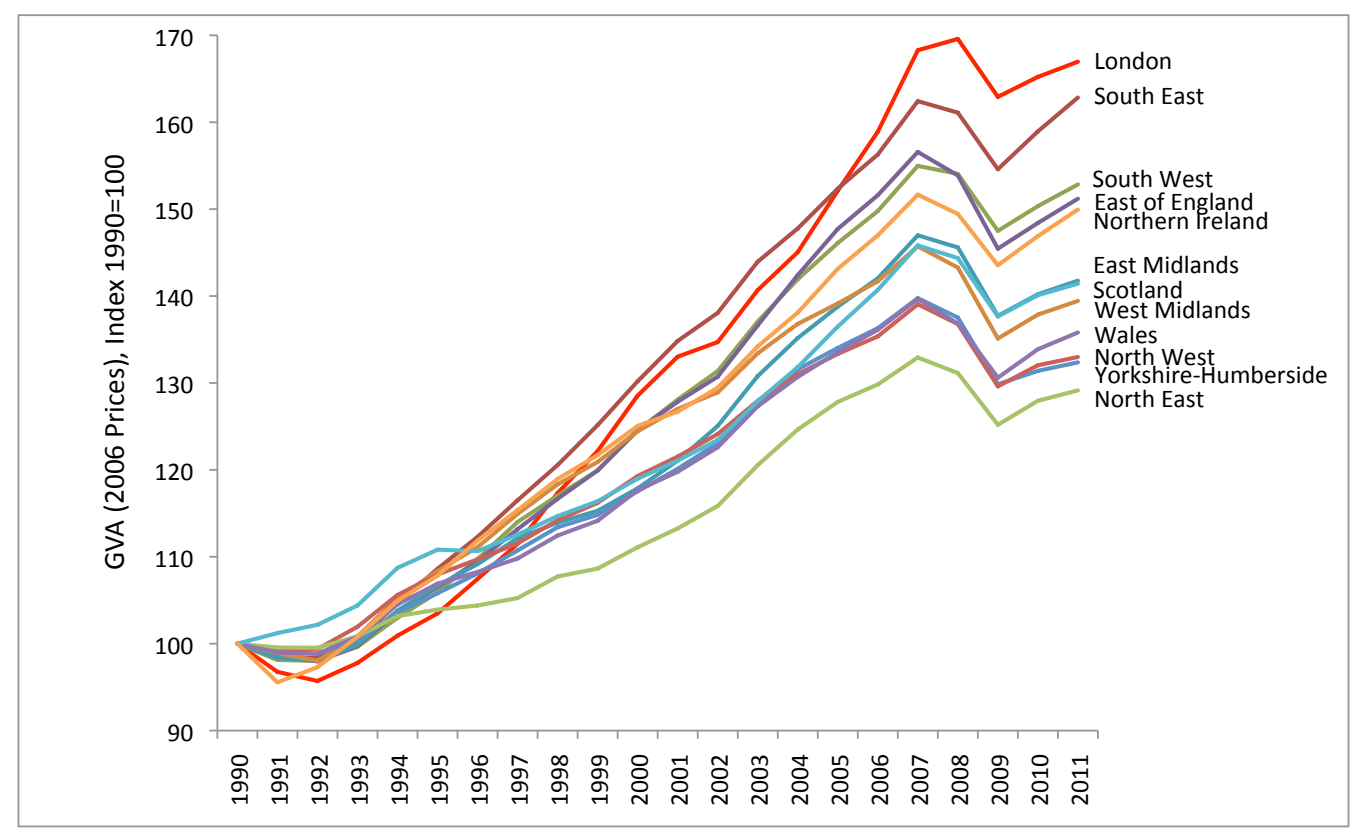

Source of Data: Cambridge Econometrics Regional Economic Data Base Note: The data are workplace based, and refer to where the output was produced, and not to where the incomes (or profits) associated with that output

\footnotetext{
6 Of course, these broad regional disparities conceal significant intra-regional inequalities: this has always been the case. But the relative incidence of richer and poorer localities across the regions still maps out a broad north-south geography, even if that geography is (inevitably) complex. Further, whilst indicators such as GDP and GVA are typically used to measure regional disparities, they capture only certain facets of local economic performance and activity, and as such do not convey the full range of factors that determine 'wellbeing' and 'quality of life.' Nevertheless, there is typically a strong correlation between local GDP per head and local variations in health, educational attainment, and the like.
} 
Table 2: Spatial Imbalance in the UK Economy, 1988-2013: Regional GDP per Capita Relative to the UK Average (UK=100)

\begin{tabular}{|lrrrrrr|}
\hline UK=100 & $\mathbf{1 9 8 8}$ & $\mathbf{1 9 9 3}$ & $\mathbf{1 9 9 8}$ & $\mathbf{2 0 0 3}$ & $\mathbf{2 0 0 8}$ & $\mathbf{2 0 1 3}$ \\
London & 152 & 149 & 152 & 162 & 169 & 172 \\
South East & 102 & 102 & 106 & 108 & 109 & 110 \\
East of England & 97 & 95 & 99 & 100 & 97 & 94 \\
South West & 93 & 92 & 89 & 92 & 92 & 91 \\
East Midlands & 97 & 94 & 93 & 90 & 88 & 83 \\
West Midlands & 93 & 92 & 93 & 88 & 85 & 83 \\
Yorks-Humberside & 91 & 90 & 89 & 87 & 84 & 81 \\
North West & 92 & 91 & 89 & 87 & 86 & 85 \\
North East & 85 & 86 & 80 & 78 & 76 & 74 \\
Wales & 85 & 84 & 79 & 76 & 72 & 72 \\
Scotland & 99 & 101 & 96 & 94 & 96 & 94 \\
N Ireland & 75 & 79 & 81 & 79 & 79 & 77 \\
Coefficient of Variation (\%) & $\mathbf{1 8 . 8}$ & $\mathbf{1 7 . 8}$ & $\mathbf{1 9 . 5}$ & $\mathbf{2 2 . 9}$ & $\mathbf{2 5 . 5}$ & $\mathbf{2 6 . 9}$ \\
\hline
\end{tabular}

Source of Data: ONS. The currently used Government Office regions in this table differ slightly from the former old Standard Regions shown in Table 1, and also include Northern Ireland. The data are also workplace based, rather than residence based.

Figure 2: The Cumulative Output (GVA) Growth Gap between the South and North of the UK, with Greater London also shown separately,

1971-2011

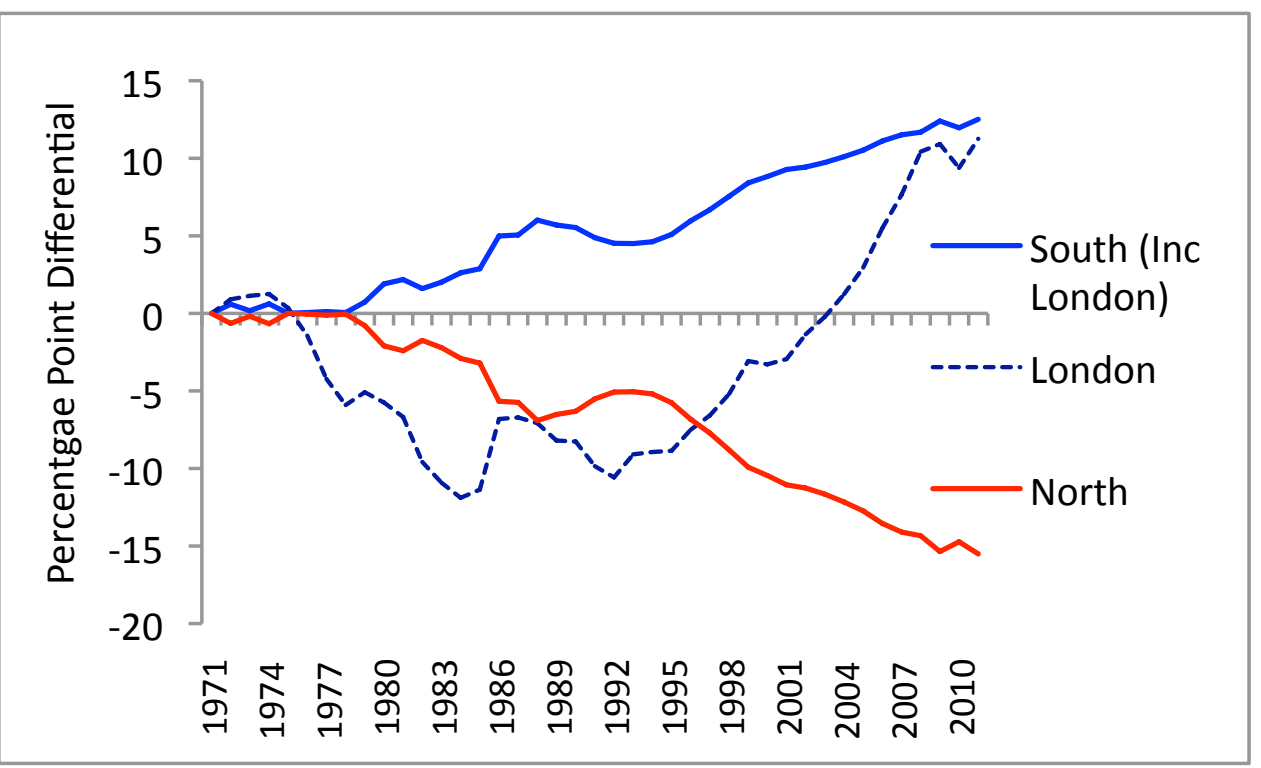

Note: Difference between each area's annual percentage growth rate and the UK average rate, cumulated over time. 'South' - Greater London, South East, South West, East of England, East Midlands; 'North' - West Midlands, Yorkshire-Humberside, North West, North East, Wales, Scotland and Northern Ireland

Source of Data: Cambridge Econometrics Regional Economic Data Base 
industrial history. And while the UK is not alone in experiencing increasing spatial imbalance, it does appear that the process has been much more pronounced there than in most other European countries (Table 3). So why does spatial economic imbalance matter, and what is the case for pursuing greater spatial balance?

Table 3: Spatial Imbalance in Selected EU Countries: Coefficient of Variation in Regional GDP per Capita, (PPS, NUTS2 Regions)

\begin{tabular}{|llll|}
\hline $\begin{array}{l}\text { Coefficient of } \\
\text { Variation (\%) }\end{array}$ & $\mathbf{1 9 8 0}$ & $\mathbf{2 0 0 1}$ & $\mathbf{2 0 1 1}$ \\
United Kingdom & $\mathbf{0 . 3 1}$ & $\mathbf{0 . 3 6}$ & $\mathbf{0 . 4 5}$ \\
France & 0.15 & 0.18 & 0.19 \\
Netherlands & 0.17 & 0.20 & 0.21 \\
Italy & 0.32 & 0.28 & 0.22 \\
Belgium & 0.43 & 0.44 & 0.37 \\
Spain & 0.14 & 0.19 & 0.15 \\
Greece & 0.35 & 0.21 & 0.14 \\
Germany & 0.35 & 0.23 & 0.23 \\
EU-15 & 0.32 & 0.28 & 0.33 \\
\hline
\end{tabular}

Source of Data: European data from Cambridge Econometrics, European Regional Data Base

\section{What is the Case for Spatial Economic Rebalancing?}

It would clearly be wholly unrealistic to expect indicators of economic performance and well-being to be identical across geographic space. There will always be local and regional differences in economic structure, business types, workers' skills, technology, and the like, so we can never expect perfect equality of wages, per capita incomes, productivity and so on between regions or cities. The constant flux of the modern economy, driven by the 'laws of coercive competition' (Harvey, 2006) and by new knowledge and technologies, propels a perennial gale of 'creative destruction' (Schumpeter, 1942) that is highly unlikely to be spatial neutral in its impacts; while at the same time, the barriers and frictions to the movements to labour, if not capital and knowledge, prevent the instantaneous self-correcting adjustments beloved of free-market economics. In this sense 'perfect' spatial balance is an unachievable goal, and is at best an ideal or abstract 'reference point'. But when the degree or level of spatial economic imbalance becomes large and 
entrenched, or increases over time, then it does become a source of concern, and raises questions over the use of human and physical resources, about spatial and individual equity, about opportunity, and about the economic and social costs that might be associated with such imbalance. As we saw in the previous section, regional per income disparities across the UK have widened progressively in recent decades, and are amongst the highest to be found in the leading OECD countries. At the present time, per capita GDP in London is double that in the northern regions (Table 3), and this level of core-region dominance is noticeably greater than in any other European Union state.

Now some spatial economists might well argue that the failure, for example, of factor prices and productivity to equalize across regions can nevertheless be given an equilibrium interpretation, and hence is not problematic. The very persistence of regional disparities might even be taken as evidence that some sort of 'compensating differentials' mechanism is operating, for example workers' trade-offs between income and amenity. On the other hand, persistent spatial inequalities need not be evidence of any sort of equilibrium. And even if regional economic imbalance is argued to be a market equilibrium outcome, this does not mean that it maximizes social welfare, or that some other alternative equilibrium that actually increases welfare is unachievable. Much depends on how we define the welfare function.

Traditionally, discussions around the case for redressing regional economic disparities have tended to emphasise either economic efficiency or social equity. According to the first of these, persistent regional imbalances in economic activity are nationally inefficient, since the under-utilization and underperformance of workers and productive capacity in 'lagging' regions mean that national wealth is lower than it could otherwise be. Policies that raise the utilization and productivity of human and capital resources in such regions (without lowering the utilization and productivity of resources in 'leading' regions) will thus raise the performance not only of 'lagging' regions but also of the national economy as a whole. At the same time, according to this view, reducing regional disparities also aids national economic management. For example, national expansion can be pursued without leading to full-employment bottlenecks and inflationary overheating in certain (core) regions whilst significant under-utilization of labour and capital still exists in others. The fact that certain other European countries have achieved comparable or even superior long-run national growth rates to that of the UK whilst having significantly lower levels of spatial economic imbalance (smaller regional economic disparities), suggests that there may be real efficiency gains from securing greater spatial economic balance across 
the UK.

According to the social equity argument, a strong case can be made for greater regional balance on welfare and equality of opportunity grounds, irrespective of economic efficiency imperatives. The underlying motivation here is the belief that individuals should not be seriously and systematically socially disadvantaged with respect to job opportunities, housing conditions, health, access to public services and the like, simply by virtue of living in one region rather than another. We know that areas which persistently suffer from low wages, inferior employment opportunities and job insecurity tend to have lower rates of educational attainment, higher rates of child poverty, ill-health and crime, and lower life expectancy, than areas with high incomes and more favourable labour markets, and that such conditions can become selfreproducing over time. It might be argued that persistent unfavourable social and economic conditions in a region should encourage people to move to where such conditions are more favourable. But there is copious evidence to indicate that it tends not to be the unemployed, low skilled and low paid that readily undertake or are able to make such movements, and that it is the more skilled and enterprising workers who move. If maintained over long periods of time, the net exodus of such workers from slower growing regions to the faster growing more prosperous ones might well benefit the latter, but will seriously deplete the human capital base in the former. At the same time, however, the persistent net movement of labour into the more prosperous, higher-growth regions can create pressures on housing markets, public services, infrastructures and the like in such areas, which pressures may well then require additional public expenditures in those regions in order to prevent costs and congestion rising.

Seeking greater spatial economic balance can thus help not only to raise national economic growth but also to secure social cohesion and citizenship, and reduce expenditures on welfare support measures, as well as serve to prevent inflationary pressures arising in core regions. In essence, the economic efficiency and social equity arguments can be argued as being as complementary and mutually beneficial, although the relative weight given to these two perspectives in policy-discourse may depend on the prevailing political-economic ideology. The basic point, however, is that national efficiency and social equity can be jointly supporting rationales for pursuing greater spatial balance in the economy.

However, there has long been a strand of economic theory that has taken a different view, to the effect that there is a 'trade-off' between efficiency and 
equity: that securing greater social equity may come at the cost of a lower rate of national growth. ${ }^{7}$ Over recent years this 'trade-off' thesis has been challenged, both theoretically and empirically: for example, endogenous growth theory can be used to argue that in fact an economy with a more equal society (in terms of education, skills or incomes) will tend to grow faster over the long run than a more unequal one. And empirical evidence tends to support this prediction. But if this holds for social equity, why should it not hold also for spatial equity? Nevertheless, as I will elaborate below, 'trade-off' thinking is not far below the surface in some versions of the new spatial economics (including the New Economic Geography (NEG), wherein some adherents argue that greater spatial agglomeration of economic activity may benefit national growth, at least up to a certain level of spatial imbalance, so that policy intervention to reduce regional disparities is brought into question.

There is then, a real need for regional studies scholars to engage with this issue, and to set out the arguments for reducing spatial economic disparities. While concern over such disparities is often there in the background, or is implied, it is less often confronted head on. In their concern to explore and elaborate the various factors that make for successful regional development, regional studies scholars have tended to let the normative question of regional socio-economic equity slip to the background. Yet, persistent spatial disparities in socio-economic opportunity and achievement raise real issues of social justice, issues that may not be readily reduced to or easily represented by model-based welfare functions, efficiency-equity trade-off curves, and the like. Our theories of regional development should, then, be capable of explicitly considering the case for a more spatially balanced economy.

\section{The Limitations of Existing Theory, I: The New Spatial Economics - An Obsession with Agglomeration and Equilibrium?}

Theoretical debate over the issue of balanced versus unbalanced economic growth is hardly new. Disagreement over the relative merits of each have long characterized development economics, where controversy goes back to the 1940s and 1950s. No sooner had the idea of 'balanced growth', defined as the simultaneous and coordinated expansion of several sectors, been

\footnotetext{
7 The classic source of this 'trade-off' idea is of course Okun (1975).
} 
proposed than it was countered by those advocating 'unbalanced growth', that is a model of growth based on concentrating resources in certain key specialisms. Some of this discussion spilled over to the issue of spatially balanced or unbalanced growth, and whether spatial imbalance may be inevitable and even desirable at early stages of national development, but is likely to be followed by spatially balanced growth at later stages. Embedded in these arguments were assumptions that eventually specialisation could lead to diversification via backward and forward linkages, and that spatial imbalance could lead to regional convergence via various 'trickle down' and 'spread effects' effects, though some authors accepted that such convergence might also require policy intervention (Myrdal, 1957; Alonso, 1968). Now most of this discussion referred to countries undergoing early development, not to advanced post-industrial economies. But over the past two decades the emphasis given to the advantages of spatial agglomeration - in effect to spatial imbalance - has received renewed attention in the new spatial economics, especially in New Economic Geography models (NEG) and New Urban Economics (NUE) models. ${ }^{8}$

Though they differ in their specific theoretical foundations and focus, both NEG and NNUE models assign considerable importance to spatial agglomeration and equilibrium outcomes: the former mainly on coreperiphery type patterns of regional economic activity, at all spatial scales; the latter mainly on the concentration of economic activities and jobs in cities, particularly large, dense cities. What links these two strands of theory is a stress on the benefits of various types of increasing returns effects and positive externalities that arise from the spatial agglomeration of firms and workers. ${ }^{9}$ There is in fact an in-built bias towards regional agglomeration and spatial economic imbalance in NEG models (Neary, 2001; Garretsen and Martin, 2010). Only at very high transport costs or other barriers to the free inter-regional movement of goods, workers and firms, or where agglomeration rapidly generates congestion costs, is a balanced geographical distribution of economic activity a stable equilibrium outcome in these models. Where such costs or barriers are low, then a spatially balanced economic landscape (where

\footnotetext{
8 In fact, in his Development, Geography and Economic Theory, Krugman (1995) argued for reviving the earlier work in development economics and linking it to economic geography via new advances in economic theory and modeling technique.

${ }^{9}$ At first glance, there would appear to be a major distinction between NEG and NUE, in as much that the former seems to stress increasing returns to scale within firms, whilst the latter emphasises external increasing returns to city size and density. But in fact this distinction is often blurred, and one can find both types of increasing returns invoked by both camps, and some general expositions of agglomeration in the economic landscape meld the two in their accounts (see, for example, Fujita and Thisse, 2002).
} 
economic activity is more or less equally distributed between regions) is potentially unstable, and the system is easily 'tipped' into a spatially unbalanced distribution, with firms and workers concentrated mainly in one region. Furthermore, such an outcome is a stable equilibrium one. To be sure, there have been some serious attempts to move away from this agglomeration bias (see the discussion in Brakman, Garretsen and Marrewijk, 2009), but a basic problem with all NEG models is that they only give clear cut analytical results in a two-region setting, or at best a multi-region setting where all regions (represented as spaceless points) are equi-distant from one another (see Garretsen and Martin, 2010).

The key point is that in NEG work, spatial agglomeration (spatial economic imbalance) is seen not only as a logical market outcome under the presence of increasing returns and mobility of factors, but also one that is deemed to increase national overall growth, at least as long as congestion costs and other negative externalities do not become dominant (see Baldwin et al, 2003; Coombes, Duranton and Gobillon, 2012). In empirical work, typically the problem of congestion costs and other negative externalities is either played down, or else attributed to the presence of factors that are inhibiting the free play of market forces, such as planning rules restricting the supply of land in core regions (the agglomerations).

In addition, although NEG models allow for certain types of interdependencies between regions (in terms of the movement of workers and firms), and for certain (though highly restricted) forms of imperfect competition, they normally assume an economy with no State activity or public sector. In reality, or course, the spatial distribution of economic activity is highly influenced by the State, in terms of the spatial distribution of public expenditure, for example on infrastructure, on education, and so on, as well as by macro-economic fiscal and monetary management. To the extent that public investment is spatially uneven it can serve to produce or reinforce spatial imbalances in economic growth. The State may undertake large scale transport investments in a particular region or city in order to reduce congestion costs; in so doing such expenditures may merely encourage further agglomeration and congestion in the area, which then require yet further public infrastructural spending, and so on. In the UK, London typifies this circular process. On the other hand, NEG models can be used to conduct valuable 'what if' exercises (Martin and Sunley, 2011a), to determine the possible (equilibrium) outcomes of deliberate public policy interventions such as public transport infrastructure investment between or within regions (such as the proposed High Speed 2 link from London to Birmingham, Manchester 
and Leeds in the UK). But in general, State spending and policy, or other key institutions such as the financial system, are not included as integral, structural components of the hypothetical spatial economies that typify NEGtype models.

These omissions and limitations notwithstanding, NEG models have exerted considerable influence on policy-makers. ${ }^{10}$ The arguments that spatial agglomeration is essentially a 'natural' market-driven process, that spatial imbalance in the economy is an equilibrium outcome and, moreover, a nationally efficient one that maximizes national growth, all play to a political disposition towards minimal intervention in the spatial economy. Indeed, the implication of NEG models is that policies that seek to reduce regional economic imbalance may in fact be nationally inefficient: in other words, that a policy 'trade-off' does indeed exist between the pursuit of national growth and the reduction of spatial economic imbalance. One finds this strand of thinking in the World Bank's report on global development, in OECD and European Commission papers on regional development, and in UK policy papers. As one exponent of these models puts it, in relation to regional economic disparities across the European Union:

Spatial agglomeration of economic activities ... may have positive efficiency effects... there is no need for European regional policy to deal with intranational regional inequalities (P. Martin, 2005, pp. 99-100, 107).

And similarly, according to an internal UK Treasury paper:

Theory and evidence suggests that allowing regional concentration of economic activity will increase national growth. As long as economies of scale, knowledge spillovers and a local pool of skilled labour result in productivity gains that outweigh congestion costs, the economy will benefit from agglomeration... policies that aim to spread growth amongst regions are running counter to the natural growth process and are difficult to justify on efficiency grounds, unless significant congestion costs exist" (HM. Treasury, 2006, emphasis added)

A further acceptance of this view is evident in the more recent UK Government paper on Understanding Local Growth, which develops its arguments firmly on the basis of NEG theory:

This new understanding [the New Economic Geography] of how economics works across space also alters the expected equilibrium. As both people and firms move to areas of high productivity there will be no simple convergence of productivity levels. Even with fully functioning markets, there can be an uneven

10 In the UK, both NEG and NUE models have permeated policy thinking in several major Government Departments, including the Treasury, the Department for Business, Innovation and Skills, and the Department for Communities and Local Government. 
distribution of economic performance, and persistent differences that are not necessarily due to market failure (Department of Business, Innovation and Skills, 2010, p. 23.)

There is no doubt that the NEG type thinking that gives rise to such views can be highly persuasive, and difficult to contest. NEG models have a mathematical exactitude that impresses policy-makers, as does their appeal to efficient equilibrium outcomes, and to market failures as the main rationale for policy intervention. This same mathematical formalism also differs sharply, of course, from the less quantitative, often more narrative based approaches that are frequently found in regional studies and economic geography. The empirical evidence on the 'trade-off', however, is far from unequivocal. For example, whilst some studies claim to find a positive relationship between national growth and the degree of spatial agglomeration or regional inequality (Dall'erba and Hewings 2003; P. Martin 2005; Crozet and Koenig 2007), others do not (Sbergami 2002; Bosker 2007; Martin, 2008; Gardiner et al., 2008). To add to this ambiguity, Krugman himself (2009) has recently voiced some doubt as to whether increasing returns to spatial agglomeration are as important as they once were:

\begin{abstract}
there's good reason to believe that the world economy has, over time, actually become less characterised by the kinds of increasing returns effects emphasized by new trade theory and new geography. In the case of geography, in fact, the peak impact of increasing returns occurred long before the theorists arrived on the scene (p.569).
\end{abstract}

Similar sentiments have been voiced by others (for example, McCann and Acs, 2011).

What of NUE theory? In these models, the focus is very much on the benefits and advantages that accrue from the density of activity and population within cities: density is alleged to increase interaction, spillovers, market opportunities, productivity and wages. Particular emphasis is put on the agglomeration of human capital: a city's success depends on having a highly skilled and well educated workforce, and the more successful is a city (in terms of high wages, high productivity and so on) the more it will attract such workers (see, for example, Glaeser and Saiz, 2004; also Moretti, 2013). There is no doubt that skilled, educated and enterprising workers are drawn to cities; after all job opportunities, wages and market openings are all greater there. What is at issue is just how big cities have to be to gain from this agglomeration and the externalities it produces: do such positive effects necessarily continue to increase with increases in city size? 
What is curious about much NUE is that cities are treated almost as 'freefloating islands', in the sense that their precise location is of secondary importance. A highly successful city - such as Boston in the US, or Cambridge in the UK - could in effect be anywhere within their respective countries. The argument is that once the 'individual' effects (skill, occupation and the like) of workers are 'controlled' for, 'place' effects are negligible and real spatial economic disparities (in real wages for example) all but disappear. Thus according to one such analysis:

\begin{abstract}
our general finding is that most of the observed regional inequality in average wage in Britain is explained by 'sorting' or 'people' rather than 'places'. Our preferred estimates, which include the individual fixed effects, suggest that the contribution of individual characteristics to variation in wages is between 100 to 850 times larger than the contribution of area effects (Gibbons et al, 2011).
\end{abstract}

Now this study and others like it have used some sophisticated techniques such as different variance decomposition measures and fixed effects crosssection econometric models - to arrive at this type of conclusion. Are we then to believe that place actually does play no significant role, that the agglomeration of skilled and high wage workers in particular regions and cities - such as the London-South East region in the UK - is entirely due to spatial 'sorting' behaviour by rational workers? If so, then, again, there would appear to be little grounds for spatial or place-based policies aimed at securing a more spatially balanced economy, only general, economy-wide people-based policies (for example, to raise the education and skill levels of individuals) or measures that support small firms everywhere. If there a case for place-based policies under this view, it is for interventions that promote the benefits and dampen down any disadvantages of agglomeration (Nathan and Overman, 2013). Planning restrictions, in particular, are singled out as prime examples of barriers to the 'spatial sorting' (of workers) because they interfere with the workings of city land and housing markets (Cheshire, Nathan and Overman, 2014). This has become a common line of argument with respect to London and the South East of the UK, where, it is clamed, restrictive planning regulations and 'green belt' zoning have contributed to the shortage of housing and the high house prices in these areas, which in turn are viewed as threats to the continued economic expansion in this part of the country. There is thus a strong case, according to such authors, for removing and dismantling planning frameworks. Some NUE exponents even argue for deliberately increasing population densities in cities (Glaeser in The Atlantic, 2011) - 'building up is better than building out'. 
But can workers' skills and productivity be separated from their place of work and residence so easily? The skill base of a region or city will reflect its past economic development path, its economic structures and labour processes. And those inherited skills and practices may well influence future skills and practices. People obviously 'make' places; but places also 'shape' people by virtue of the economic structures, employment opportunities, knowledge networks, and educational and other public and social institutions that exist in given localities. The passing on of skills, learning, and spillovers of knowledge amongst workers in a local labour market are surely some of the locally-based emergent processes that characterize spatial agglomeration. A high-skill and dynamic local economy will tend to produce the spillovers and institutional and cultural forms that reinforce that locality's high-skill environment; and conversely in a low-skill less-prosperous local economy. Interestingly, Lösch himself stressed the close interrelationships between people, production and place (see Figure 3). To argue that place imparts little

\section{Figure 3: The Interrelationships between People, Place and Production} (After Lösch, 1954, p.224)

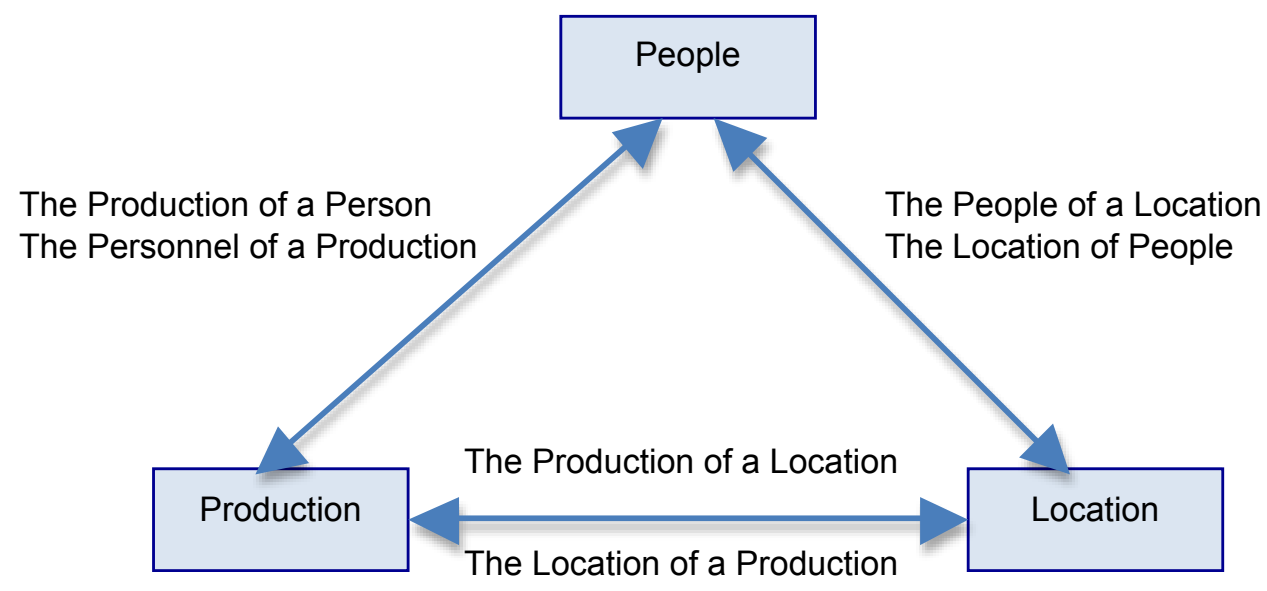

influence of its own, that skills develop independently of place, and that spatially uneven development is simply about the 'spatial sorting' of (rational, utility-maximising) workers with different attributes, is to miss these complex interrelationships, and even sophisticated econometric models may not in fact be able to identify them. Further, people move into particular places not only to find jobs, but also because those places are pleasant locations in which live: they have attractive physical, environmental and cultural assets. Even Krugman (2005) has argued that there is case for place-based policies; for example, he suggests that the local provision of high quality education 
institutions and infrastructures - key components of what he calls locallyspecific 'fundamentals' - can indeed be a valid focus of regional and urban policy. And some urban economists such as Moretti (2013) also seem to be coming round to a similar view that the success of a city has to do with placebased attributes as much as with human capital alone.

All this is certainly not meant to deny that the agglomeration of economic activity in core regions or principal cities confers real and significant economic advantages - of course it does; nor to dispute the key role of major city-regions in today's globalizing world (see, for example, Scott 2001; Florida 2008). The issue, rather, is first, whether NEG and NUE models offer a full and credible explanation of this phenomenon (see Martin, 1999, 2013; Garretsen and Martin, 2010), second, whether there are limits to the benefits of agglomeration, third, whether promoting larger urban agglomerations in lagging regions, like northern Britain, is the best or only way of promoting growth there, and fourth whether in fact there really is a spatial equitynational efficiency trade-off.

It is well known that productivity tends to be higher in urban agglomerations, though the estimates of how much an increase in local agglomeration - or 'economic mass' - raises labour productivity levels vary widely. For example, it has been estimated that a doubling of local density (population or employment) raises productivity by between about 2-5 percent for the USA and similarly for Europe (Ciccone, 2002; Rappaport, 2007; Abel, Dey and Gabe, 2011). These seem modest effects indeed. Such analyses, it should be noted are typically static, cross sectional in nature, rather than dynamic and developmental. And results may vary because of the different spatial scales used to measure agglomeration. Yet a further issue is whether the alleged relationship varies with the type of spatial agglomeration, for example, whether economically specialized or diversified. Further, there is the issue of congestion and environmental costs, and how far these are socialized.

At the same time, there is ample evidence, across Europe and the USA, that the largest cities are not necessarily the fastest growing in terms of output or employment. In the UK, it has been the smaller cities - especially those in the south of the country - that have dominated the growth league table over the past three decades (Figure 4; see Martin, Tyler and Gardiner, 2014). London aside, the other large cities and conurbations of Birmingham, Sheffield, Manchester, Liverpool and Newcastle, all in the North, have lagged well behind in the growth of both output and employment (Figures 4 and 5). The spatial economists would argue that this finding is not at all inconsistent with 
urban economics models, and cannot be used to criticize the latter. Yet, at the same time, these same authors claim that the poor performance of the UK's northern cities is due in part to the fact that these cities are not large enough (Overman and Rice, 2008). They argue that these cities are smaller than one would predict from Zipf's Law. The presumption is that if they were larger, they would enjoy greater increasing returns effects and hence higher productivity and higher wages. But as Paul Krugman (1996) himself has cautioned, Zipf's Law does not necessarily fit an economy where the primary city is also the national capital, as is the case with London in the UK:

many countries, for example, France and the United Kingdom, have a single 'primate city' that is much larger than a line drawn through the distribution of other cities would lead you to expect. These primate cities are typically political capitals: it is easy to imagine that they are essentially different creatures from the rest of the urban system (1996, p. 41, emphasis added).

A similar point is made by Gabaix (1999), who argues that:

In most countries Zipf plots usually present an outlier, the capital, which has a bigger size than Zipf's law would warrant. There is nothing surprising there because the capital is a peculiar object, driven by unique political forces (op cit, p.756, emphasis added).

The fact of the matter is that the evidence for Zipf's law is weak in general (Soo, 2005).

With respect to the UK, London is indeed a very 'different creature' from the rest of the country's urban system, and its economy is most certainly partly driven by unique political forces. London is the location of what is one of the most centralized national political and financial systems to be found among OECD countries. It has also been the recipient - and continues to be the beneficiary - of vast sums of public expenditures and monies, on infrastructure, transport, education, health services, and major cultural institutions (estimated at £80billion a year by Oxford Economics, 2007), all of which help sustain its growth and the attraction to it of workers, firms and private sector resources. To argue that the agglomeration of activity in London is somehow 'market-driven' is quite misleading: London's economy is substantially underwritten by the state, on a per capita basis no less than, and in some cases more than, other parts of the UK.

While it might be correct to argue that the UK's major second-tier cities such as Manchester, Birmingham, Liverpool, Sheffield and Newcastle should be larger agglomerations, size itself is no guarantor of success. Some of the spatial economists, drawing again on Zipf's law, even suggest that London is 
Figure 4: Large Northern Cities Have Lagged Behind - Output and Employment Growth in 63 British Cities, 1981-2011 (Average Annual Growth Rates), Classified into South and North

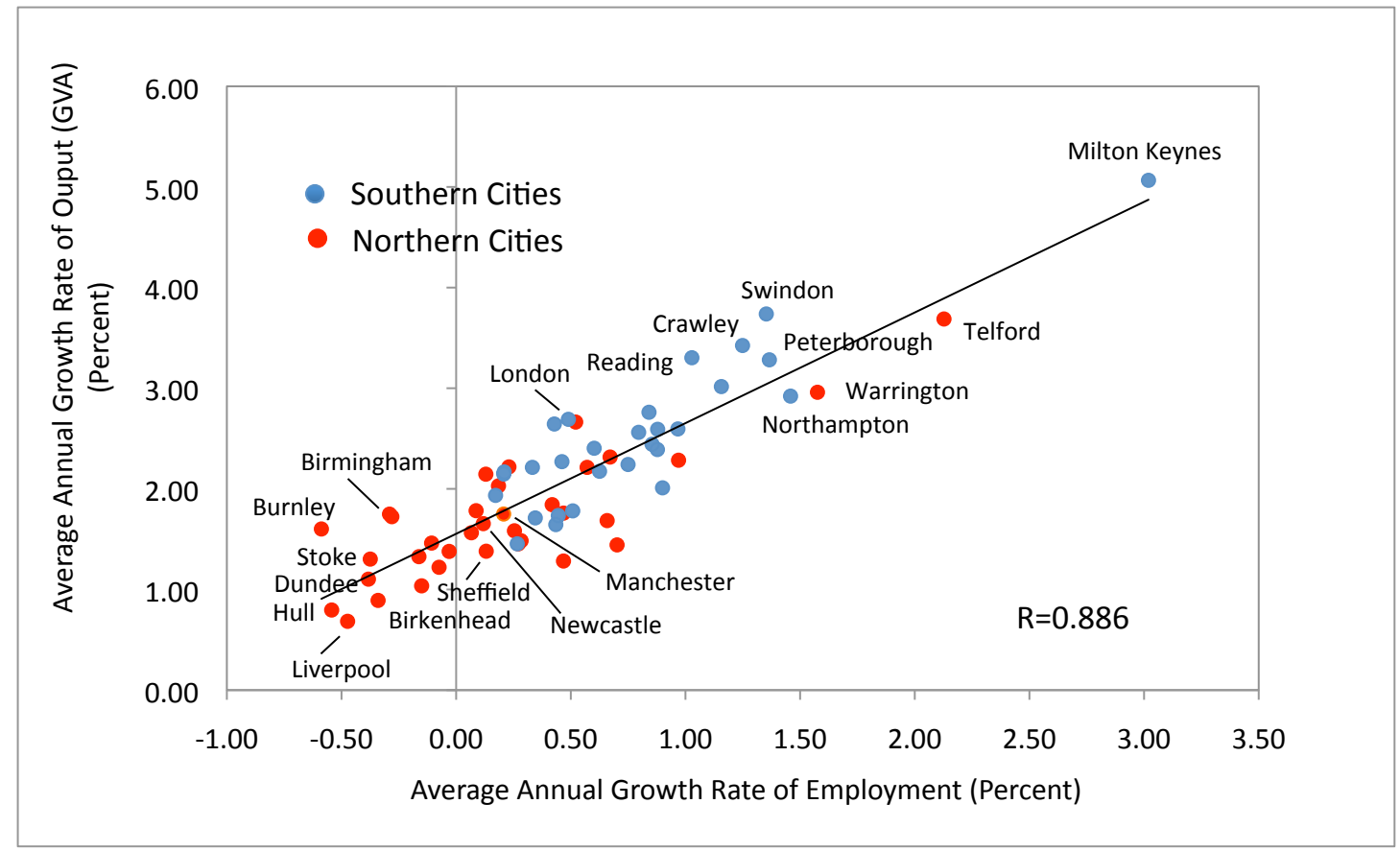

Note: Cities are those with populations of 125,000 or more in 2011 , and are the Primary Urban Areas as defined by the Centre for Cities. GVA is in 2006 prices. 'South' is defined as comprising London, the South East, East of England, South West and East Midlands regions; 'North' comprises the East Midlands, Wales, Yorkshire-Humberside. North West, North East and Scotland.

Source: Martin, Tyler and Gardiner (2014)

\section{Figure 5: Divergent Cities - Cumulative Differential Output Growth in Largest and Fastest Growing Cities, 1981-2011 \\ Cumulated Differences between City and National (GB) Annual Growth Rates (GVA in 2006 prices)}

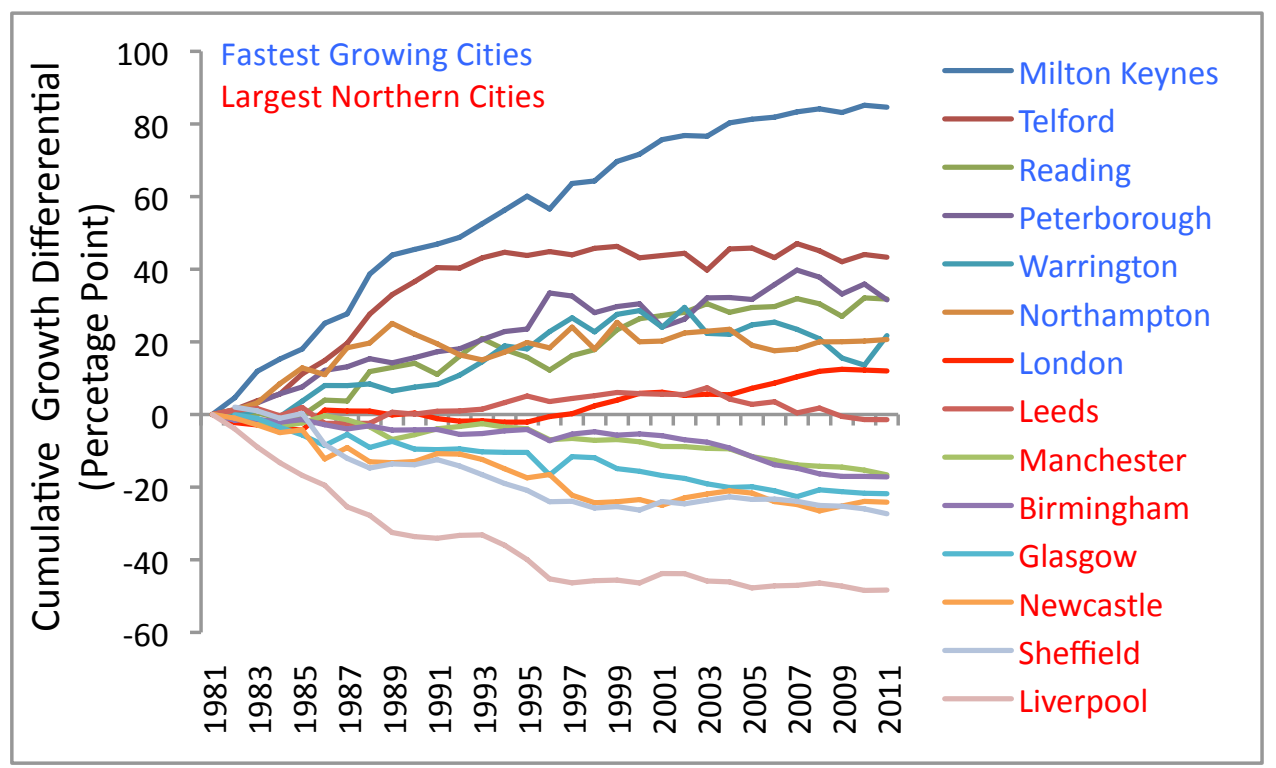

Note: Cities ranked according to their cumulative growth gap differential Source: Martin, Tyler and Gardiner (2014) 
itself is too small and, further, that if the British economy is to be spatially balanced, policy should only really focus on promoting just one other large metro-agglomeration in addition to London, a sort of northern 'mega-cityregion' (connecting up Liverpool, Manchester, Leeds and Sheffield). In contrast, the recent reports of the City Growth Commission (2014a, b, c) take a more poly-centric view, and identify 15 cities around the UK that should be the economic hubs of major city-regions. The fact is that further agglomeration need not necessarily be the answer to the economic success of northern cities; bigger is not necessarily better. There may well be limits to agglomeration; and urban agglomeration economies ebb and flow, perhaps even have 'life cycles' (Potter and Watts, 2011). The economic revival of the UK's northern cities may have as much, if not more, to do with re-orientating their economies, with substantially improving their infrastructures, with upskilling their human capital, with improving their interconnectivity, and with granting them much greater financial and political autonomy, than with size perse.

Meanwhile, the increasing agglomeration of economic activity in London and the South East pushes up wage costs, land and office rents, and house prices there. According to a recent survey of global cities, London has become the most expensive such city in the world in which to live and work (Savills, 2014). At the same time, the house price gap between London and the rest of the UK has widened dramatically over the past decade and a half, to a level unprecedented in modern history (Figure 6). Average house prices in London are almost two and a half times the national average, and more than three times those in the North. While the high house prices in London are, without question, the result of a lack of supply relative to demand, a not insignificant portion of that demand has itself been driven by another aspect of unbalanced growth, namely the extraordinary salaries and bonuses paid to those working in London's financial and professional sectors. In addition, numerous high net worth overseas investors, including some overseas sovereign wealth funds, have been keen to own and benefit from a slice of the capital's real estate. For many such investors, property in London is a safe hedge in a turbulent global financial system. It is not surprising that London has been the epicenter of the last three house price booms, in the late-1970s, late-1980s and the 2000s, which have then spread outwards across the rest of the country. In this sense, London has been a recurring source of inflationary pressure, itself another aspect of spatial economic imbalance. 
I am certainly not arguing that the new spatial economics offers no useful insight into the processes and advantages of spatial agglomeration. To the contrary, it has greatly advanced our understanding of that phenomenon. Some of the results from these models are powerful and instructive. But the new spatial economics leads too readily to the view that spatial agglomeration is the only or main game in town, and that it is almost everywhere a nationally efficient, market-driven equilibrium outcome. It thus also leads all too easily to an opposition - or at least a very suspicious attitude - to place-based policy intervention, unless the focus of that policy is to remove what are regarded as impediments to the free functioning of markets (especially city land and housing markets). It is not surprising, therefore, that some critics have attacked the obsession with agglomeration, city size and deregulation as 'urban boosterism' in all but name (Haughton, Deas and Hinkcs, 2014), a charge strongly rejected by the spatial economists (Overman, 2014). I tend to side with the critics. The case for making London ever larger, while at the same time promoting the formation of a northern 'mega-city' equivalent, is far from proven. Furthermore, I would raise other concerns. Neither NEG nor NUE have much to say about how and why cities and regions differ in their

Figure 6: Regional House Price Gaps and the London Phenomenon: Average House prices, 1973(4)-2014(2)

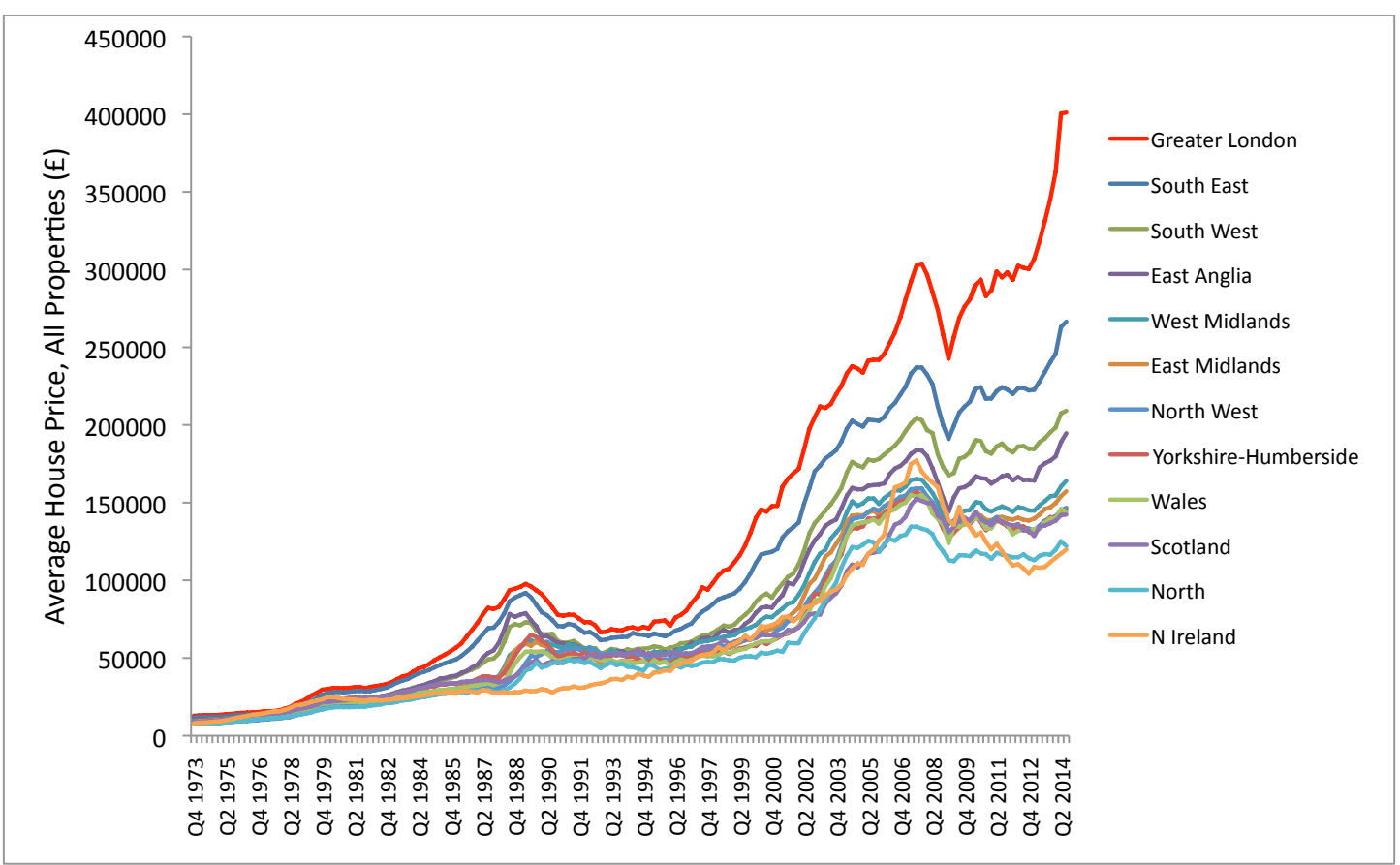

Source: Nationwide House Price Statistics, Historical Series 
adaptability to economic change - how they evolve over time; and they also largely ignore or relegate the role of institutional and political structures in shaping spatial economic development (other than including some simplistic indicators, dummy variables or 'fixed effects' to try to capture their influence). While NEG and NNUE may provide some valuable insights into the spatial structure of the economy, these frameworks are incomplete as explanations, and provide only a partial guide for correcting major spatial imbalances. The undue influence exerted by these approaches on much official policy thinking in the UK and elsewhere can thus be questioned.

\section{The Limitations of Existing Theory, II: Regional Studies - A Surfeit of Concepts in Need of Synthesis?}

But if the new spatial economics has limitations, what do regional studies and economic geography have to say? A decade and a half ago, Ann Markusen (1999) seriously questioned whether regional studies had much relevance, either for our understanding of regional problems or for influencing policy making. Her critique - that regional studies was littered with fuzzy concepts, that it lacked empirical depth, and that it suffered from what she called 'policy distance' - elicited a sharp rebuke from among certain regional studies scholars and economic geographers (see Regional Studies, 2003). Perhaps her critique was exaggerated, though I believe it was not far off the mark.

More recently, Hadjimichalis and Hudson (2014) have voiced different concerns, in this case that the European crisis has exposed major weaknesses not just in NEG type theory but also in regional studies and economic geography. Their critique is that neither body of work says much about the crisis or about the process of combined and uneven development. I have considerable sympathy with this argument. Although it is perhaps tempting to view Europe's crisis as an unexpected shock, albeit one from which the recovery is slow, it can also be seen as a manifestation of deeper-seated systemic problems associated with the interaction between Europe's particular (and asymmetric) form of monetary union and its geographies of uneven development (see Martin, 2001; Fingleton, Garretsen and Martin, 2015).11 Not only does spatially unbalanced growth between and within the member states of the Eurozone pose problems for a monetary union that

\footnotetext{
11 In fact not dissimilar concerns were raised some forty years ago by Magnifico (1973). He queried whether the European nations met the criteria necessary for successful monetary union, in part because of regional disparities in economic performance and inflation proneness across member states.
} 
lacks accompanying fiscal union, as is the case of the Eurozone (Martin, 2001), the restrictions associated with a common currency in turn have major implications for the process of uneven regional development in and among the member countries. Time was when economic geographers and regional theorists talked seriously about 'combined and uneven regional development' and sought to theorise and critically interrogate this process in terms of the fundamental mechanisms and structures that underpin capitalist growth. But this paradigm has all but disappeared from current thinking. ${ }^{12}$ Why is this?

Hadjimichalis and Hudson attribute this disappearance largely to an academic obsession within regional studies with the study of 'successful' regions and localities. There is no doubt that much of regional studies and economic geography over the past two decades or so has focused on success stories, on high-tech regions and clusters, on dynamic regional innovation systems and networks, on so-called 'creative' cities, on examples of 'smart' governance and leadership, and the like. By comparison, less attention has been directed to problem regions and cities, to areas that have lost their former dynamism or economic roles, or to why such places become locked into inferior growth paths, how they might be revived on a new developmental path, and how far and in what ways the fortunes of regions is linked to patterns of dependency and interaction.

Perhaps the overwhelming emphasis on successful regions is understandable: these are obviously much more exciting to study than depressed and lagging regions, and prominent personal academic careers and even global public acclaim can more easily be forged by championing success stories (witness Michael Porter's promotion of 'clusters' and Richard Florida's credo of 'creative' classes and cities). ${ }^{13}$ Given that much of the period from the mid1980s to the onset of the crisis in 2007 was one of growth and rapid technological change, regional studies naturally focused on those regions, cities and clusters and industries that appeared to be leading this new phase of expansion. Further, not only has the focus been on success stories, the urge to 'read off' policy lessons from these stories has proved irresistible: if only depressed, economically lagging regions and cities could replicate some of the features found in successful regions and cities - develop clusters, build a

\footnotetext{
12 Among the relatively few remaining stalwart torch bearers, David Harvey of course stands out (eg Harvey, 2006).

13 Both Porter and Florida have become something of global 'policy celebrities', consulted by governments around the world eager to find the 'magic bullet' of local, city and regional economic success, in the first case by promoting clusters, in the second by attracting so-called 'creative' people and industries.
} 
regional innovation system, attract the creative classes, pursue 'smart specialization', or secure good local leadership and governance, for example then their economies would be revived.

What we seem to do in regional studies and economic geography is to lurch from one concept - dare one say, fad - to another. One moment it is regional innovation systems, at another learning regions, at yet another clusters, then supply chains, more recently smart specialization, global production networks, and regional resilience, and so on. Likewise, a succession of theoretical perspectives has appeared over the past three decades, including regulationist, Schumpeterian, institutional, network-orientated, relational, and evolutionary. I am as guilty as anyone in contributing to this burgeoning array of (partial) concepts and paradigms. It would be quite wrong to suggest that none of these ideas has had no impact on policy. The notions of clusters, creative cities, and more recently, smart specialization are three obvious examples that have resonated with policy-makers. Clusters in particular have become widely regarded as an absolutely essential component, the sine qua non, of the regional policy tool kit. Yet, although a highly geographical notion, it was the business economist Michael Porter who, by cleverly linking clusters explicitly with firm competitiveness, developed and promoted this idea and made it so attractive to the policy-making community (Huggins and Izushi, 2011). To be sure, regional studies scholars and economic geographers have enthusiastically expanded on and enriched Porter's work in various ways, and we now know much more about the internal dynamics of clusters, about their various localisation economies, their role in knowledge production and so on. However, the alleged advantages of clusters (that they promote greater innovation, productivity and growth) have not gone uncontested (for example, Cooke, Asheim and Martin, 2006; Martin and Sunley, 2003, 2011; Duranton, 2011), and we still know relatively little about how clusters actually emerge or how they evolve and adapt over time (Martin and Sunley, 2011b). Further, few studies demonstrate just how far, and under what circumstances, they act as engines of wider regional growth and spatial economic development (Martin and Sunley, 2011). And perhaps most problematically, few clusters studies link them into the wider, global economic systems in which cluster firms compete and interact with one another. While clusters can, under specific circumstances, form a valuable part of a regional or urban development strategy, in general the case for cluster policies remains theoretically ambiguous and empirically equivocal (Duranton, Martin, P. and Mayer, 2010; Duranton, 2011; Asheim, Cooke and Martin, 2006; Martin and Sunley, 2011c). Even if they are necessary elements 
of a strategy for spatially rebalancing a national economy like that of the UK, of themselves they are far from sufficient.

Then take specialization. According to some (for example Michael Storper, 2013) specialization is the motor of city and regional growth. But is it? Again, the theoretical arguments are ambiguous, and the evidence very mixed. Economic geographers and regional studies experts have long debated whether sectoral specialization or sectoral variety is the most conducive to regional economic performance. This debate has echoes of the balanced versus unbalanced growth debate within development economics, mentioned above. Any impartial reading of the literature on whether specialization or diversification is better for regional and city growth would indicate that the matter is still undecided, and confused: one can find examples to support both views (Duranton and Puga, 1999). One can point to certain present-day regions and cities that owe their economic growth and success to specialization. But one can equally point to regions and cities that formerly enjoyed economic success based on this or that specialization but which are now languishing economically. At the same time, one can point to successful

Figure 7: Specialisation and Growth in 63 UK Cities (Krugman Specialisation Index, Average 1981-2011, and Average Growth Rate of GVA, 1981-2011) ${ }^{14}$

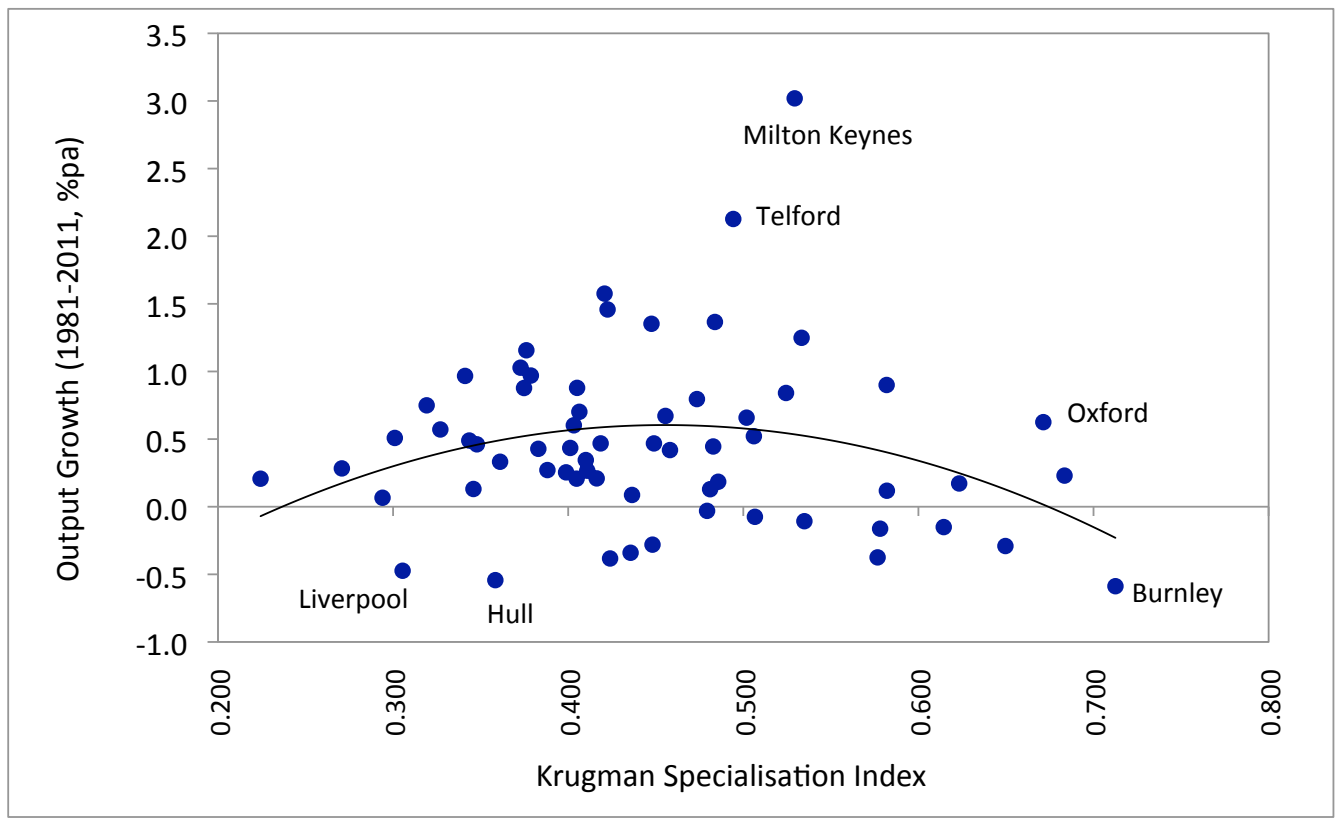

Source: Martin, Tyler and Gardiner (2014)

\footnotetext{
14 The Krugman relative specialisation index for a region or city is the sum over industries of the absolute differences between each industry's share of regional or city employment and its corresponding share of national employment. It ranges from a minimum of 0 to a maximum of 2 . The 63 cities are those with populations of 125,000 and over.
} 
regions and cities that have diversified economic structures. And while American scholars tend to argue that US cities have become more specialized and have diverged in their economic structures (Berry and Glaeser, 2005; Moretti, 2013; Storper, et al, 2014), the evidence on British cities suggests that the trends here are somewhat different, and that if anything cities have been undergoing structural convergence (O'Donoghue, 2000; Martin, Tyler and Gardiner, 2014). Certainly for the UK there is no clear relationship between specialization and growth; what relationship there is appears to be curvilinear, positive up to a certain degree of specialization, but negative thereafter (Figure 7). However, overall, the relationship is weak.

And so the debate goes on. ${ }^{15}$ Some have sought to resolve the specializationversus-variety impasse by introducing other concepts, for example 'diversified specialization' and 'related variety', the former referring to the case where a region's or city's economy is dominated by, say three or four major sectors of activity (Farhauer and Kröll, 2011), the latter to a situation where a number of sectors share complementary knowledges, technologies or inputs (Frenken, Van Oort and Verburg, 2007). Yet again, however, the logic underpinning these ideas is not unassailable. Just how many (or how few) dominant sectors are needed to define 'diversified specialisation'? And in the case of 'related variety' surely it matters what the sectors are that are related - and how they are related? Relatedness among similarly weak, declining or lagging sectors may have quite different consequences from relatedness among a group of dynamic, buoyant activities. In addition, the extent of relatedness may be crucial: a certain degree of relatedness may be advantageous, but a high degree of relatedness across a high proportion of a region's or city's industries may in fact be a source of region- or city-wide economic and technological lock-in, and of low resilience to shocks. And what if a region's or city's related variety is in fact dominated by, or dependent on just a few major producers? This could be growth inducing or potentially destabilising. What ultimately matters for a region's (or city's) economic success is its export base (see Rowthorn, 2010), or more precisely the diversity of and sophistication of the products and services a region makes and trades, and thence how it 'fits into' the wider national and international spaces of production, technology and trade. ${ }^{16}$ A region's or city's economic

\footnotetext{
15 See Palan (2010) for a useful evaluative survey of the range of different measures that have been used to measure structural specialisation and diversity.

16 For an interesting approach to measuring and tracking how national regional and city economies 'fit into' product and technological space, and how the complexity of that fit seems to be correlated with economic success, see Hausmann et al (2013).
} 
performance reflects the composition of its productive output and the structures that emerge to hold and combine knowledge. In this respect, there is no doubt that much of northern Britain has experienced difficulty in developing and attracting new types of activity and productive knowledge to replace the sustained loss of its manufacturing economy over the past thirty years. But theory does not provide a clear guide as to what these new activities or knowledges should be.

One could go on to examine the numerous other concepts, ideas and paradigms that have emerged in regional studies in recent years. Surveying this literature, it can rightly be argued that we have learned much about certain aspects and sources of spatial economic development and how space and place matter for technological change, innovation, creativity and enterprise. Likewise, there is growing evidence that the quality and direction of local leadership and governance arrangements can be influential. Each of these ideas and paradigms provides a valuable lens on the process of regional development. In this sense, the positive feature of all this cumulative collective intellectual enterprise is that it has produced a much wider palette of potential determinants of regional growth than one finds in the new spatial economics. There are however, two less positive and interrelated features. The first has been the sheer proliferation of concepts, all vying for our attention, and the fact that each of these various concepts provides only a partial explanation of uneven regional development. The second is that in the rush to devise new concepts and new empirical examples, we seem to have lost sight of certain aspects of the bigger picture, the big processes and large structures, within which uneven regional development occurs: most of the analyses and accounts one finds in regional studies seem detached from the fundamental forces and logics of capital creation, circulation and accumulation.

On the issue of proliferation, no sooner, it seems, has one new concept arrived on the regional studies stage than another is already waiting impatiently in the wings. What we have been much less successful at is integrating and connecting this expanding plethora of partial theories and concepts by means of larger interpretive schemas, organizing principles or frameworks so as to give them some measure of coherence. While we generally extol conceptual diversity for its power to detect multiple facets and features of a complex reality, we need to be wary of the price that can be paid for cultivating it. The greater the diversity of concepts, theories and methods, the greater the difficulty of finding common denominators that link them, of knowing under what conditions and circumstances the different, multi-scalar determinants of 
regional development come into play and interact to determine particular outcomes. This is really important if we want to influence policy. Influence comes not just from amassing numerous concepts, partial theories, case studies, or empirical facts. It also comes from effective synthesis and integration. We seek to know the 'causes' of regional development, we undertake analyses of this or that 'cause'. But relatively few such findings are sufficient of themselves to provide a full understanding of, let alone a means of ameliorating, the problem of combined and uneven regional development. As a UK Government research analyst recently quizzed me: "I've read a lot of regional studies articles and books over the past months and am bewildered by the sheer range of ideas about the determinants of regional growth and development. As a policy-advisor, just what do I do with all these? Is it just a 'pick-and-mix' issue, and if it is, when, where and what do I pick and mix?" Good questions. This is where the new spatial economics does score over regional studies since it is at least able to claim that the same basic model based on the tension between agglomeration (centripetal) forces on the one hand and dispersion (centrifugal) forces on the other - applies at all spatial scales; to quote some of its leading exponents:

the models we construct to analyse many different issues turn out to have similar 'deep structures'. The same equations reappear, albeit with somewhat different interpretations of the parameters, and the qualitative behaviour of the model economy usually turns on a couple of repeated expressions reflecting the tension between centripetal and centrifugal forces (Fujita et al, 1999,p. 345).

Whilst, as I have argued above, it is working this tension far too hard to expect it to provide a full, historically informed and contextualized explanation of uneven regional development, the lack of any integrative framework or principles in regional studies is just as problematic.

The task here, as I see it, is twofold. The first is to link and ground our various partial ideas and concepts in some sort of encompassing schema that sets out how the various determinants and causes of regional economic development identified within the regional studies literature come together and interact to explain how particular patterns and forms of uneven regional development have evolved to be what they are, and how they are continuing to evolve. Relatedly, the second is to refocus our analytical lens more firmly on the question of how the particular cases and instances of regional development we study relate to the wider system(s) of which they are a part - how uneven 
regional development is a combined, relational process. ${ }^{17}$ We sometimes study individual instances of regional development as a means of grasping the peculiarities of specific cases. Often we adopt a universalizing perspective, in which we are interested in establishing that every case of a particular type of regional development follows essentially the same 'rules' and displays the same sorts of mechanisms and processes. ${ }^{18}$ Less often, we seek generalizing accounts, in which the aim is to establish a principle of variation in regional development by examining systematic differences among regions. What we do even less, I suggest, is to attempt to construct encompassing explanations that seek to compare and account for differences in growth and development between regions by placing them within the same system, on the way to explaining their characteristics as a function of their varying relationship to the system as a whole. The idea of 'encompassing comparisons' as a method, indeed goal, of explanation is taken from Tilley (1989). He suggests that encompassing explanations are necessarily concerned to give meaning to specific instances of a phenomenon in terms of their relationship to a larger system, and that in forging such explanations the focus is not just on the specifics of each case but also on the 'big processes' and large structures' that link and bind those cases together as a system. It is the multifarious ways in which the individual cases relate the larger 'whole' that imbues both the cases and the whole with complexity.

Opinions will differ, of course, over what form an encompassing framework for regional studies should take. Some might recoil from the mere suggestion that we should be seeking such an encompassing approach at all, arguing that it carries the dangers of monism, reductionism and functionalism. In economic geography particularly, but also in regional studies, over the past two decades there has been an explicit and deliberate move away from general explanatory frameworks, holistic thinking, or meta-principles, a move that has merely encouraged the very proliferation of diverse concepts and approaches with which we are now confronted. Indeed, such diversity is actively celebrated by some. We have a plurality of regional development accounts, often with limited exchange between them. As Barnes and Sheppard bemoan, the discipline (they are referring to economic geography, but the same can be said of regional studies more generally) is being

17 One of the earliest attempts to emphasise the combined nature of uneven regional development, drawing on a fusion of Harrod- type economic growth and instability theory, agglomeration theory, monopoly theory, and notions of cumulative causation, is Holland (1976). No-one reads this study any more, yet its attempt to integrate several ideas into a general account of regional economic imbalance still holds some valuable lessons for today.

18 This is precisely the intention behind NEG models, as the previous quote by Fujita and Thisse illustrates so well. 
"increasingly fragmented into a series of intellectual solitudes that has created isolation, producing monologues rather than conversations" (2010, p. 193). In response they have called for an 'engaged pluralism', which they define as an approach "based on dialogue, translation, and the creation of trading zones... that recognizes and connects a diverse range of circulating local epistemologies: a politics of difference rather than consensus" (op cit. p.193, emphasis added).

But as Simandan (2011) has cogently argued, a commitment to 'engaged pluralism' along these lines seems to arise as much from a rejection of the possibility of an integrating or unifying ambition as from a concern over the proliferation of partial and competing knowledge claims. Indeed their argument seems explicitly to reject the idea of consensus around a commonly agreed theoretical and methodological framework or set of principles by means of which to unify and integrate different sets of ideas about uneven regional development. But how do we make the connections between, and create a dialogue among, the diverse range of 'local epistemologies' that make up regional studies, if not by agreeing on some common, unifying or encompassing principles (in effect the 'rules of engagement')? Encompassing approaches to the study of regional development would have the twin advantages of directly taking account of the interconnectedness of ostensibly separate regional experiences and of providing a strong incentive to ground analyses explicitly in the historical contexts of the structures and processes they include.

Confronted with an entrenched configuration of spatial disparities in relative economic growth and prosperity - of the sort we find in the UK - we need to move back in time, looking for the crucial choices and events - rapid or gradual - that set places on different paths of development. The precocity or lateness (or even absence) of industrialization; the disruptive, creative (but also destructive) force of major technological advances; the coercive pressures of new and emerging international competitors (that is, the expansion and development of the global economy); the emergence of new sectors of economic activity and new circuits of capital; shifts in the form and orientation of State interventions in the management, regulation and governance of the economy; these and other 'big' processes and 'large' structures constitute the encompassing conceptual framework within which the processes and mechanisms that have led to present geographical disparities have to be explained. It is within such an historically inflected encompassing framework that we can then ground specific 'timeless' and abstract conceptual schemas - such as clusters, agglomeration, specialization, 
and so on - which thereby both acquire and contribute explanatory meaning. The idea then is to explain the evolving uneven geographical development of a country like that of the UK as a cumulative consequence of its regions' and cities' connections to and involvement in the differentiating processes that have transformed the economy over time, up to the present.

The emphasis on 'cumulative' here is intentional. What we are dealing with studying and explaining the evolving pattern of uneven geographical development in any economy is a complex process of spatially biased cumulative causation, not just of economic growth and development but also of political-institutional evolution. The heterodox economist Mark Setterfield (1997), for example has suggested that the notion of cumulative causation should be a foundational principle of non-equilibrium-historical economics. This is interesting since according to the economic geographer Allen Scott, any attempt to understand the process of uneven regional development must

formulate the problem by reference to a dynamic of cumulative causation whose logic is definable not in terms of some primum mobile or first cause, but in terms of its own historical momentum... this points ... to the importance of an ontology of regional growth and development that is rooted in the idea of path dependent economic evolution and recursive interaction (2006, p. 85).

Unfortunately, economic geographers and regional studies scholars have never thoroughly developed or analysed the idea of circular and cumulative causation (even if they have invoked the terminology), yet it is fundamental for subsuming and synthesizing many of the 'drivers' of regional development that have come to populate contemporary regional studies. Cumulative causation takes place at all spatial scales, within the individual firm, within clusters, cities, regions and at the global level. It occurs in innovation, skill formation, and in institutional and political governance, indeed in almost every aspect of economic development and evolution.

Indeed, the attraction of the circular and cumulative causation idea as it was developed by early exponents such as Veblen and Myrdal, was as a form of heterodox, non-equilibrium political economy that explained the dynamics and spatialities of growth in terms of the self reinforcing interaction of economic and, crucially, institutional and political structures and processes (Martin, 2015). Regrettably, in subsequent work the institutional and political dimensions were downplayed or dropped entirely, so that the notion became more or less narrowly synonymous with increasing returns models of export driven growth, especially under Kaldor's influence (see, for example, 
Kaldor, 1981). As Krugman $(1991,1995)$ himself has openly conceded, this made the idea easy to formalise mathematically, which in turn made it an attractive ingredient of NEG models, where it has lost any vestige of institutional and political significance and, ironically, has become a mechanism making for spatial equilibrium (see Bhattacharjea, 2010)!

In the past few years, however, heterodox economists have begun to revive the political economy and historical dimensions of circular and cumulative causation (eg. Toner, 1999; Berger, 2009; Setterfield, 2010). In this work, circular and cumulative causation emerges as a complex system of ideas whose strength lies in viewing technical phenomena, such as increasing returns and agglomeration externalities, as inseparable from historical, institutional, political and cultural processes. As mentioned above, the UK, for example, has one of the most spatially centralized financial systems and state forms of any OECD nation. Both are highly concentrated in London, and largely controlled from there. State spending and the national policy-making apparatus are London based and London centric. The banking system is overwhelmingly concentrated there, as are the stock market, venture capital and private equity markets, pension fund institutions and the whole raft of legal and professional services that help support those financial circuits. Time was when the UK had a regional banking system, regional stock markets, and city and local authorities raised the bulk of their finances locally. Today, all three are concentrated and controlled from London. As Dow (1999) has argued, to the extent that a nation's financial system becomes increasingly concentrated organizationally and increasingly centralized spatially, especially if focused on a national financial centre that is also a global financial hub - as is the case with London - the more likely is that system to experience a cumulatively reinforced economic imbalance between the centre and the regions. It would be stretching credulity to argue that the success of London and the surrounding South East is simply due to the rational 'spatial sorting' of workers and firms and has had nothing to do with the historical cumulative concentration of the nation's key financial, institutional and political structures there, or that this concentration of financial, corporate and political power and decision-making has played no role in the growth and persistence of spatial economic imbalance between the North and South of the country. In effect, the recursive circular and cumulative forces making for spatial economic imbalance in the UK have themselves become institutionalized, embedded in the national political economy, itself spatially concentrated in and controlled from London. Understanding the political and institutional nature of this cumulative historical process is vital: the role of such factors as 
regional differences in specialization, technological innovation, skills and so on has to be set within this national political economy.

An encompassing explanatory framework, therefore, should insist on the interaction of the economic, political, institutional and social. It is necessarily historical and evolutionary in orientation. The tension between the geographical concentration and dispersion of capital is only one tension that produces uneven regional development. Another is that between continuity and change, between the preservation of old development paths and spatial forms and the creation of new paths and forms. A key principle of regional studies, therefore, is that it should be concerned with how economic landscapes evolve and the role of 'creative destruction' in that process, why evolution (creative destruction) occurs unevenly across space, why economic change is led by certain cities and regions in one period, but by others in a different period, or why some cities and regions perhaps manage to lead and dominate successive phases of economic change. We need an approach that takes history seriously because we cannot understand the present, nor begin to fashion policies to shape the future, unless we understand how we have got to where we are and hence where and what the focus of policy intervention should be (Boschma and Martin, 2010). An evolutionary perspective has a number of advantages. ${ }^{19}$ It makes no assumptions or presumptions about equilibrium in the economic landscape; instead, it stresses dynamics. It directs us to examine the path dependent nature of uneven regional development, but at the same time what makes for the uneven adaptability of city and regional economies, including the role of innovation and the creation of novelty, new variety and new paths in that process (Martin and Sunley, 2006; Martin, 2010).

Not only should encompassing conceptual map be historical and evolutionary in orientation, so too it should assign primary importance to the political and institutional. It is fashionable to argue that with globalization, national states have become increasingly powerless and irrelevant. While they have certainly lost some of their authority and autonomy to global capital, they nevertheless remain powerful actors in shaping how their cities and regions succeed and compete in the wider international economy. The state is the primary vehicle to assure the creation and stability of the collective conditions for production, consumption and exchange: as such the national political-administrative

19 As the late and eminent urban scholar, Sir Peter Hall, once put it:

"As is commonly the case with the geography of a complex economic unit, the present makes no sense until it is related to the evolutionary process which has produced it." (Peter Hall, The Industries of London, 1962) 
system is always an active agent in capital circulation and accumulation and how these are distributed across space. In these neoliberal times, states compete one with another to 'capture' and 'fix' a share of increasingly mobile capital within their territories - for example, by creating a low-tax, weaklyregulated 'good business climate' and, where the opportunity exists, as in the UK, by promoting and supporting their 'global city' - even if that means that other cities and regions are neglected or disadvantaged in the process. Of course, states differ in the extent to which they have engaged in this neoliberal mode of economic governance. But the basic point stands: national political-administrative and economic governance systems and their territorial structures (for example, whether highly centralized or devolved) can significantly influence the geography of economic growth and development within their jurisdictions, through their macro-economic policies, taxation and spending priorities, funding of infrastructures, welfare programmes and so on. And how they attempt to mediate or resolve the periodic crises of capitalism through fiscal and monetary measures can likewise have highly spatially differentiated and unequal outcomes, witness the spatially uneven impact that current fiscal austerity programmes are having across many countries. In the same way that the institutional forms and structures of a given national political economy have been argued to influence its 'variety of capitalism' and its comparative advantage (Hall and Soskice, 2001), so it might be expected that those same institutional forms and structures will shape that nation's internal geographies of economic growth and prosperity.

In short, what we need is we need an 'evolutionary-historical geographical political economy' within which our various partial theories and explanatory schemas could be given coherence and focus. It is beyond my scope and remit here to set out in detail what such an encompassing framework might look like and how it might function as a structure for unifying or integrating existing approaches in regional studies. Rather, my aim is to stimulate debate and discussion around this issue, and hopefully others will take up the challenge. But it does seem to me that some such framework would offer a far more compelling account of spatial economic imbalance within (and between) countries than is provided by either NEG/NUE type models or by the plethora of regional studies ideas that now exists. An encompassing 'evolutionaryhistorical geographical political economy' could be deployed in various ways. The most challenging and demanding would be a 'total national system' type of analysis, which would aim to understand and explain a nation-wide evolving pattern of combined and uneven geographical development, set in the context of that national economy's changing external global linkages and 
interactions and its evolving internal institutional and political structures. We do little if any such work. Alternatively, one could focus on just a particular region or city region, and conduct what we might call a 'total place' analysis, wherein we examine that region's or city's economy in all its multi-scalar detail, as a complex open system set within the relevant national and international networks and structures to which it relates and with which it interacts. We rarely conduct such analyses, but typically focus just on particular aspects or sectors of a given region or city. And then there are indepth 'contrastive comparisons', a variant of 'total place' analysis in which the aim is to understand why the contrasting cities or regions in question have evolved differently and possibly divergently, economically, by virtue of their different interactions with and role within their wider national and indeed global contexts. Choosing such contrastive comparisons carefully might even give us a means of undertaking 'what-if' and 'counterfactual' type enquiries. ${ }^{20}$

\section{Whither Spatial Rebalancing?}

So where does all this leave the task of spatially rebalancing the UK economy? The UK has had some form of regional policy aimed at securing a more spatially balanced pattern of growth and prosperity for close on 90 years. ${ }^{21}$ The fact that spatial disparities across the economy still persist - and have widened over the past three decades - suggests that previous policies have not achieved as much as was hoped or intended. It would be tempting to argue, as some do, that this confirms that regional and urban policy can never achieve much since it is trying to work against the forces of the market, which in the UK 'naturally' favour the concentration of growth in London and the South East.

A different, more realistic, but also more challenging, viewpoint is that the problem is not that regional policy is trying to work against the 'market', but against systemic features that have to do with how the economy is run, with

20 This was the sort of enquiry that Chinitz (1961) appeared to be calling for in his comparison of the contrasting economic structures and growth rates of New York and Pittsburgh, although his discussion does not situate these two cities in their wider national and international systems of interactions and dependencies. A contemporary example of what I have in mind is Storper et al's (2014) comparison of Los Angeles and San Francisco.

21 The first experiment to revive the depressed northern areas of Britain was the Industrial Transference Scheme, initiated in 1928. This 'move workers to the work' policy sought to move unemployed workers from the structurally declining coalfields in northern regions to employment opportunities in the more prosperous south. It was not a great success, and was followed, in 1934, by the Special Areas Act, in effect a 'move work to the workers' policy since it aimed to attract new industrial investment to the depressed areas. 
our economic, financial and political structures, with the priorities adopted by successive governments, and with the lack of any real political commitment to effect fundamental change; in short with the nation's large political and institutional structures, its particular form of political economy and constitutional arrangements, and how these have evolved and been reproduced. Even in the 'laissez faire' economy of the $19^{\text {th }} \mathrm{C}$ the British State played an instrumental role in fashioning the nation's economic geography. For example, the State's expansion of Empire abroad and its associated prosecution of protected markets and trade, had no small bearing on the development and success of distinctive regional industrial specializations and complexes across the country, from the heavy industries of Northern Britain to the concentration of commerce, trade, finance and political administration in London. Fast forward to the recent past and again the State has once again helped forge a new phase in the country's uneven regional development. The political decision to deregulate London's financial markets and institutions in the late-1980s by the Thatcher government was key to enabling the capital to secure a leading role in the new international economy of global finance. At the same time what power over public finance and spending that was enjoyed by local government in the regions was emasculated by the central government located in London on ideological grounds, both to shrink the state and curb what it saw as the socialist policies of Labour controlled local authorities. In various ways, the particular form and structure of the UK's political-institutional system has been, and continues to be, key to understanding the spatial imbalance within the national economy.

In terms of regional policy, the UK currently has a raft of measures to aid particular sections of industry, to promote innovation, to help cities improve their infrastructures, to assist skills, to help small business enterprise, and so on - all the sort of things that one can find academic support for within particular strands of regional studies. And no doubt these are all potentially useful. The issue is whether all these add up to a strategy capable of securing the spatial economic balancing called for by the Government. I am doubtful. I suspect that, as with past policies, at best the impact of such polices will be small since, political rhetoric notwithstanding, such measures remain piecemeal, 'add-on' and marginal to the basic structures and workings of our national system of fiscal, monetary and economic management, which will continue to favour London and its environs. As Lord Heseltine argued back in the mid-1980s, and has voiced strongly again only recently (Heseltine, 2013), the UK's highly centralized system of Government spending and political control has long militated against the regions and cities outside London, in effect acting as a 'counter-regional policy'. 
Yet is the UK at last witnessing the beginnings of an historical turning point, a distinctive turn which may possibly herald a new era in policy thinking and practice? Heseltine's (2013) call for devolving £50billion of central Government spending each year to cities and localities outside London, combined with empowering the provincial cities and city-regions with directly elected mayors, seems to have set a new ball rolling. The Coalition Government has recently devolved certain fiscal powers to a Greater Manchester combined authority, and Chancellor Osborne has recently declared that he regards the more general development of a new structure of devolved city-region governance in northern Britain in order to rebalance the economy as his great personal project (quoted in Wintour, 2015). And there is no doubt that the promised devolution to Scotland of certain tax and spending powers has fuelled a growing call for fiscal devolution by English cities ('metro-devo') of the sort Heseltine (op cit) has argued for. We might, perhaps, be on the cusp of a new national political economy that has greater spatial balance as an explicit part of its structure.

Of course, fiscal devolution is not a panacea for spatially rebalancing the economy (Rodriguez-Pose and Ezcurra, 2010). I would argue that it is a necessary condition, but not of itself automatically a sufficient one. It could end up favouring the very largest cities: London is already mounting a strong case to be allowed to keep its business rates and property taxes, and given that both land and property values are highest there, the revenues could be substantial. But by the same token, fiscal devolution could actually penalize less prosperous cities and regions and simply reinforce spatial economic imbalance across the country. Nor need fiscal devolution necessarily translate into effective and successful local economic growth and development. Furthermore, certain public expenditures and transfers will always need to remain funded and administered from the political centre. And while all the talk is of reviving and 'powering up' northern cities, what in fact is the most appropriate geographical scale or unit for tackling spatial economic imbalance. Is it cities? Or city-regions? Or regional groupings (systems) of cities ('metro-regions')? How many cities: just a select few, or all? And what about the spaces 'in between'? Notwithstanding these unresolved questions there would seem to be gathering momentum for a long-overdue restructuring of the power relations between the political centre and the cities and regions. The genie may be out of the bottle, and perhaps at last we may see a new spatial literacy emerging within Government over its role in shaping and reshaping the national space economy; in effect an historic shift in one of the 'large structures' that shapes the UK's economic landscape. How 
this new structure develops, and how far it succeeds, under a continuing regime of overall national fiscal austerity remains to be seen.

Nevertheless, what this juncture opens up, not just in the UK context, but on a wider front, is a major opportunity for regional studies analysts and economic geographers to make a convincing case for tackling uneven regional development. What I have tried to argue in this paper is for these groups to step back from their existing diversity of concepts, approaches and schemas and consider how this plethora of ideas might be combined, integrated and synthesised in order both to focus more explicitly on uneven regional development as a systemic problem, and thereby to give greater coherence, explanatory power and policy weight to their work. To my mind this will entail grounding our ideas within an encompassing framework that is evolutionary-historical in orientation, that takes political and institutional structures as foundational, which works with whole systems and not just specific parts, and which is therefore holistic in ambition. This is no trivial task. One thing is certain: it has to be a collective enterprise. I return to where I began, the call from Lösch to "let space-conditioned particularity grow, without letting the whole run wild". As he says, that is "political art". But that political art requires a convincing and relevant conceptual and empirical foundation. In many ways, Ann Markusen's complaint about 'policy distance' in regional studies still has force. Regional studies may have moved closer to addressing specific policy relevant issues - how to promote local clusters, regional innovation, better supply networks, and so on - but it is still at considerable remove from tackling the really big question of 'combined and uneven regional development' in our crisis-prone, globalising age. This, for me, is the real challenge for regional studies.

\section{References}

Abel, J.R., Dey, I and Gabe, T.M. (2011) Productivity and the Density of Human Capital, Staff Report No 444, Federal Reserve Bank of New York

Alsonso, W. (1968) Urban and Regional Imbalances in Economic Development, Economic Development and Cultural Change, 17, pp. 1-14.

Asheim, B., Cooke, P. and Martin, R.L. (Eds) (2006) Clusters and Regional Development: Critical Reflections and Exploration, London: Routledge, 289 pp.

Baldwin, R., Forslid, R., Martin, P., Ottaviano, G. and Robert-Nicoud, F. (2003) Economic Geography and Public Policy, Oxford: Princeton University Press. 
Barlow Commission (1940) Royal Commission on The Distribution of the Industrial Population, London, H.M. Stationery Office.

Barnes, T. and Sheppard, E. (2010) Nothing includes Everything: Towards Engaged Pluralism in Anglophone Economic Geography, Progress in Human Geography 34, pp. 193-214.

Bhattacharjea, A. (2010) Did Kaldor Anticipate the New Economic Geography? Yes, but..., Cambridge Journal of Economics, 34, pp. 1057-1074

http://www.federalreserve.gov/boarddocs/speeches/2004/20040220/

Berger, S. (Ed) (2009) The Foundations of Non-Equilibrium Economics, London: Routledge.

Bernard, A., Redding, S., Schott, P. and Simpson, H. (2003) All is Not Equal, Centrepiece, 143, Summer, pp. 1-7.

(http://cep.lse.ac.uk/pubs/download/CP143.pdf)

Bernanke, B. S. (2004). “The Great Moderation”, Remarks at the Meetings of the Eastern Economic Association, Washington, DC, February 20

Berry, C. and Glaeser, E. (2005) The Divergence of Human Capital Levels across Cities, Papers in Regional Science, 84, pp. 407-444.

Boschma, R. and Martin. R.L. (2010) Handbook of Evolutionary Economic Geography, Cheltenham: Edward Elgar.

Bosker, M. (2007) Growth, Agglomeration and Convergence: A Space-Time Analysis for European Regions, Spatial Economic Analysis, 2, pp. 91-100.

Brakman, S., Garretsen, H. and Marrewijk, C. (2009) A New Introduction to Geographical Economics, Cambridge: Cambridge University Press.

Brown, G. (2007) Mansion House Speech, The Mansion House, City of London. June 20, http://webarchive.nationalarchives.gov.uk/+/http:/www.hmtreasury.gov.uk/2014.htm

Cable, V. (2013) "London Draining Life out of Rest of Country", http://www.bbc.co.uk/news/uk-politics-25444981

Cameron, D. (2010) "Transforming the British Economy: Coalition Strategy for Economic Growth", Speech, 28 May, Prime Minister's Office, London. https://www.gov.uk/government/speeches/transforming-the-britisheconomy-coalition-strategy-for-economic-growth

Cheshire, P., Nathan, M. and Overman, H. (2014) Urban Economics and Urban Policy, Cheltenham: Edward Elgar.

Chinitz, (1961) Contrasts in Agglomeration: New York and Pittsbugh, American Economic Review, 51, pp. 279-289.

Ciccone, A. (2002) Agglomeration Effects in Europe, American Economic Review, 46, pp. 213-227.

City Growth Commission (2014a) Unleashing Metropolitan Growth, London: Royal Society for the Arts.

City Growth Commission (2014b) Powers to Grow: City Finance and Governance, London: Royal Society for the Arts. 
City Growth Commission (2014c) Connected Cities - The Link to Growth, London: Royal Society for the Arts.

City of London Corporation (2011) London's Competitive Place in the UK and Global Economies, Research Report, City of London Corporation

City of London Corporation (2014) London's Finances and Revenues, Research Report, City of London Corporation.

Coombes, P.-P., Duranton, G., Gobillon, L., Puga, D. \& Roux, S. (2012) The Productivity Advantages of Large Cities: Distinguishing Agglomeration from Firm Selection, Econometrica, 80, pp. 2543-2594.

Crafts, N. (2005) Regional GDP in Britain, 1971-1911: Some Estimates, Scottish Journal of Political Economy, 52, pp. 54-64.

Crozet, M. and Koening, P. (2007) The Cohesion-Growth Tradeoff: Evidence from EU Regions, Mimeo, Centre d'Économie de la Sorbonne, University of Paris.

Dall'erba, S. and Hewings, G.J.D. (2003) European Regional Development Policies: The Trade-off between Efficiency-Equity Revisited, Discussion Paper 03-T-2, Regional Economics Applications Laboratory, University of Illinois.

Deutsche Bank (2013) London and the UK Economy: In for a Penny, in for a Pound? Special Report, Deutsche Bank Markets Research.

Dijkstra, L., Garcilazo, E. and McCann, P. (2013) The Economic Performance of European Cities and City-Regions: Myths and Realities, European Planning Studies 21, pp. 334-354.

Dow, S. (1999) The Stages of Banking Development and the Spatial Evolution of Financial Systems, in Martin, R.L. (Ed) Money and the Space Economy, Chichester: Wiley, pp. 31-48.

Duranton, G. and Puga, D. (1999) Diversification and Specialisation in Cities: Why, When and Where Does it Matter? Research Papers in Environmental and Spatial Analysis No. 56, Department of Geography and Environment, London School of Economics.

Duranton, G. (2011) California Dreamin': The Feeble Case for Cluster Policies, Review of Economic Analysis, 3, pp. 3-45.

Duranton, G., Martin, P. and Mayer, T. (2010) The Economics of Clusters: Lessons from the French Experience, London: Routledge.

Farhauer, 0. and Kröll, A. (2011) Diversified Specialisation: Going One Step Beyond Economics' Specialisation-Diversification Concept Jahrbuch Für Regionalwissenschaft 32, 1, 63-84,

Fingleton, B., Garretsen, J.H. and Martin, R.L. (2014) Shocking Aspects of Monetary Union: The Vulnerability of Regions in Euroland, Journal of Economic Geography, 15, doi:10.1093/jeg/lbu055

Frenken, K., van Oort, F. and Verburg, T. (2007) Related Variety, Unrelated Variety and Regional Economic Growth, Regional Studies, 41, pp. 685697. 
Froud, J., Johal. S., Law, J., Leaver, A. and Williams, K. (2011) Rebalancing the Economy (Or Buyer's Remorse), Working Paper 87, Centre for Research on Socio-Cultural Change, The Open University, Milton Keynes.

Fujita, M. and Thisse, J-F. (2002) Economics of Agglomeration: Cites, Industrial Location and Regional Growth, Cambridge: Cambridge University Press.

Gabaix, X. (1999) Zipf's Law for Cities: An Explanation, Quarterly Journal of Economics, 114, pp. 739-67.

Gardiner, B., Martin, R.L. and Tyler, P. (2013) Spatially Unbalanced Growth in the British Economy, Journal of Economic Geography, 13, pp. 889-928.

Garretsen, J.H. and Martin, R.L. (2010) Rethinking New Economic Geography Models: Taking Geography and History More Seriously, Spatial Economic Analysis, 5, 2, pp. 127-160.

Gibbons, S., Overman, H. and Pelkonen, P. (2010) Wage Disparities in Britain: People or Places? Discussion Paper 60, Spatial Economics Research Centre, London School of Economics.

Glaeser, E.L. (2005) Reinventing Boston, 1630-2003, Journal of Economic Geography, 5, pp. 119-153

Glaeser, E. L. (2009) Why Has Globalization Led to Bigger Cities? The New York Times (http://economix.blogs.nytimes.com/2009/05/19/why-hasglobalization-led-to-bigger-cities /?_php=true\&_type=blogs\&_r=1\&) (Accessed August 29, 2014).

Glaeser. E. (2008) Cities, Agglomeration and Spatial Equilibrium, Oxford: Oxford University Press.

Glaeser, E. L. (2012) Triumph of the City, Basingstoke: Macmillan.

Glaeser, E. L., Kallal, H. D., Scheinkman, J. A., and Shleifer, A. (1992) Growth in Cities, Journal of Political Economy, 100, pp. 1126-1152.

Glaeser, E. and Gottlieb, (2009) The Wealth of Cities: Agglomeration Economies and Spatial Equilibrium in the United States, NBER Working Paper 14806, National Bureau of Economic Research, Washington DC.

Hadjimichalis, C. and Hudson, R. (2014) Contemporary Crisis Across Europe and the Crisis of Regional Development Theory, Regional Studies, 48, pp. 208-218.

Hall, P. (1962) The Industries of London, London: Hutchinson.

Hall, P.A. and Soskice, D. (2001) Varieties of Capitalism: The Institutional Foundations of Comparative Advantage, Oxford: Oxford Univesrity Press.

Harvey, D. (2006) Spaces of Global Capitalism: Towards a Theory of Uneven Geographical Development, London: Verso.

Haughton, G., Deas, I. and Hincks, S. (2014) Making an Impact: When Agglomeration Boosterism meets Antiplanning Rhetoric, Environment and Planning, $A$, 46, pp. 265-270.

Hausmann, R. Hidalgo, C.A., Bustos, S., Coscia, M., Simeos, A. and Yildirim, M.A. (2013) The Atlas of Economic Complexity: Mapping Paths to Prosperity, Cambridge, Mass: MIT Press.

Henderson, V. (2003) The Urbanization Process and Economic Growth: The 
So-what Question, Journal of Economic Growth, 8, pp. 47-71.

Heseltine, M. (2012) No Stone Unturned: In Pursuit of Growth, London: Department for Business, Innovation and Skills.

HM Government (2010) Local Growth: Realising Every Place's Potential, Cm 7961, London: The Stationery Office.

Hobor, G. (2013) Surviving the Era of Deindustrialization: the New Economic Geography of the Urban Rust Belt, Journal of Urban Affairs, 35, pp. 41743.

Holland, S. (1976) Capital Versus the Regions, London: Macmillan.

Huggins, R. and Izushi, H. (Eds) (2011) Competition, Competitive Advantage and Clusters: The Ideas of Michael Porter, Oxford: Oxford University Press.

Kaldor, N. (1981) The Role of Increasing Returns, Technological Progress and Cumulative Causation in the Theory of International Trade and Economic Growth, Économie Appliquée, XXXIV, pp. 593-617.

Konzelmann, S. (2014) The Political Economy of Austerity, Cambridge Journal of Economics, 38, pp. 701-714.

Kotkin, J., Cox, W., Modarres, A. and Renn, A.M (2014) The Problem with Mega-Cities, Centre for Demographics and Policy, Chapman University.

Krugman, P. (1991) Increasing Returns and Economic Geography, Journal of Political Economy, 99, pp. 483-99

Krugman, P. (1996) The Self-Organising Economy, Oxford: Blackwell.

Krugman, P. (1995) Development, Geography and Economic Theory, Cambridge, Mass: MIT Press.

Krugman, P. (2005) Second Wind for Industrial Regions? In Coyle, D., Alexander, W. and Ashcroft, B. (Eds) New Wealth for Old Nations, Oxford: Princeton University Press, pp. 35-47.

Krugman, P. (2009) The New Economic Geography, Now Middle-Aged, Regional Studies, 45, pp. 1-7.

Lee, C. (1979) British Regional Employment Statistics, 1841-1971, Cambridge: Cambridge University Press.

Lösch, A. (1939) The Economics of Location, English Translation, 1954, New Haven: Yale University Press.

Magnifico, G. (1973) European Monetary Unification, New York: Wiley.

Markusen, A. (1999) Fuzzy Concepts, Scanty Evidence, Policy Distance: The Case for Rigour and Policy Relevance in Regional Studies, Regional Studies, 33, pp. 869-884.

Marksuen, A. and Schrock, G. (2006) The Distinctive City: Divergent Patterns in Growth, Hierarchy and Specialisation, Urban Studies, 43, pp. 13011323.

Martin, P. (2005) The Geography of Inequalities in Europe, Swedish Economic Policy Review, 12, pp. 85-108. 
Martin, R.L. (2001) EMU Versus the Regions? Regional Convergence and Divergence in Euroland, Journal of Economic Geography, 1, pp. 51-80

Martin, R.L. (2004) The Contemporary Debate over Britain's North-South Divide: Images and Realities of Regional Inequality in late-20 $20^{\text {th }}$ Century Britain, Ch 2. in A.R.H. Baker (Ed) Geographies of England: The NorthSouth Divide, Imagined and Material, Cambridge: Cambridge University Press, pp. 15-43.

Martin, R.L. (2006) The Localisation of Industry, Ch. 52 in Raffaelli, T., Becattini, G. and Dardi, M. (Eds) The Elgar Companion to Alfred Marshall, Edward Elgar, pp. 393-401.

Martin, R.L. (2008) National Growth Versus Regional Equality? A Cautionary Note on the New Trade-off Thinking in Regional Policy Discourse, Regional Science, Policy and Practice, 1, 1, pp. 3-13.

Martin, R.L. (2010a) Uneven Regional Growth: The Geographies of Boom and Bust under New Labour, in Coe, N. and Jones, A. (Eds) The Economic Geography of the UK, London: Sage, pp. 29-46.

Martin, R.L. (2010b) Roepke Lecture in Economic Geography - Rethinking Regional Path Dependence: Beyond Lock-in to Evolution, Economic Geography, 86, pp 1-27.

Martin, R.L. (2011) The 'New Economic Geography': Credible Models of the Economic Landscape? In Leyshon, A., Lee, R., McDowell, L. and Sunley, P. (Eds) The Sage Handbook of Economic Geography, London: Sage, pp. 5371.

Martin, R.L. (2013) London's Economy: From Resurgence to Recession to Rebalancing, in Tewdwr-Jones, M., Phelps, N. and Freestone, R. (Eds) The Planning Imagination: Peter Hall and the Study of Urban and Regional Planning, London: Routledge, pp. 65-84.

Martin. R.L. (2015) Cumulative Causation, Endogenous Growth and Regional Development, in Dunford, M. et al (Ed) Encyclopedia of Geography: People, the Earth, Environment and Technology (Forthcoming)

Martin, R.L. and Sunley, P.J. (2003) Deconstructing Clusters: Chaotic Concept or Policy Panacea? Journal of Economic Geography, 3, 1 pp. 5-35.

Martin, R.L. and Sunley, P.J. (2011a) The New Economic Geography and Policy Relevance, Journal of Economic Geography, 11, pp. 357-370.

Martin, R.L. and Sunley, P.J. (2011b) Conceptualising Cluster Evolution: Beyond the Life Cycle Model? Regional Studies (Special Issue on Cluster Evolution, (Eds. R. Boschma and D. Fornahl), 45, pp. 12991318.

Martin, R.L and Sunley, P. J. (2011c) Regional Competitiveness: Clusters or Dynamic Comparative Advantage? In Huggins, R. and Izushi, H. (Eds) (2011) Competition, Competitive Advantage and Clusters: The Ideas of Michael Porter, Oxford: Oxford University Press, pp. 211-238.

Martin. R.L., Tyler, P. and Gardiner, B. (2014) The Evolving Economic Performance of British Cities, Working Paper 4, Foresight Programme on The Future of Cities, UK Government Office for Science, London. 
McCann, P. and Acs, Z. (2011) Globalization: Countries, Cities and Multinationals, Regional Studies, 45, pp. 17-32.

Moretti, E. (2013) The New Geography of Jobs, Boston: Mariner Books.

Myrdal, G. (1963) Economic Development and Underdeveloped Regions,

Nathan, M. and Overman, H. (2013) Agglomeration, Clusters and Industrial Policy, Oxford Review of Economic Policy, 29, pp. 383-404.

Neary, J.P. (2001) Of Hype and Hyperbolas: Introducing the New Economic Geography, Journal of Economic Literature, XXXIX, pp. 536-561.

O'Donoghue, D. (2000) Some Evidence for the Convergence of Employment Structure in the British Urban System from 1978 to 1991, Regional Studies, 34, pp. 159-67.

Okun, A.M. (1975) Equality and Efficiency: The Big Trade-Off, Cambridge, Mass; The Brookings Institute.

Osborne, G. (2014) 'We Need a Northern Powerhouse', Speech delivered in Manchester 23 June,

(https://www.gov.uk/government/speeches/chancellor-we-need-anorthern-powerhouse)

Overman H, (2014) Commentary. Making an impact: misreading, misunderstanding, and misrepresenting research does nothing to improve the quality of public debate and policy making, Environment and Planning A 46 2276-2282

Overman, H. and Gibbons, S. (2011) Unequal Britain? How Real are Regional Disparities, Centre Piece, 17, 1, pp. 21-25.

Overman, H. and Rice, P. (2008) Resurgent Cities and Regional Economic Performance, SERC Policy Paper 1, June 2008.

Oxford Economics, (2007) London's Place in the UK Economy, 2007-2008, Report for the City of London Corporation, London: Oxford Economics

Palan, N. (2010) Measurement of Specialisation: The Choice of Indices, Working Paper 62, Forschungsschwerpunkt Internationale Wirtschaft, Vienna.

Potter, A. and Watts, H.D. (2011) Evolutionary Agglomeration Theory: Increasing Returns, Decreasing Returns and the Industry Life Cycle, Journal of Economic Geography, 11, pp. 417-455.

Rappaport, J. (2007) Consumption Amenities and City Population Density, Research Working Paper 06-10, Federal Reserve Bank of Kansas City.

Regional Studies (2003) Responses to Markusen, Regional Studies, 37, pp. 719751.

Rodriguez-Pose, A. and Ezcurra, R. (2010) Is Fiscal Decentralisation Harmful for Economic Growth? Evidence from the OECD Countries, Journal of Economic Geography, 11, pp. 619-643.

Rowthorn, R.E. (2010) Combined and Uneven Development: Reflections on the North-South Divide, Spatial Economic Analysis, 5, pp. 363-388. 
Savills (2014) London overtakes Hong Kong as most Expensive Place to Live and Work, Savills 12 Cities Report, London.

http://www.savills.com/_news/article/105347/178949-

0/09/2014/london-overtakes-hong-kong-as-most-expensive-place-tolive-and-work

Sbergami, F. (2002) Agglomeration and Economic Growth: Some Puzzles, HEI Working Paper No. 02/2002, Graduate Institute of International Studies, Geneva.

Schumpeter, J. A. (1942) Capitalism, Socialism and Democracy, London: Routledge.

Scott, P. (2007) The Triumph of the South: A Regional Economic History of Early Twentieth Century Britain, Farnham: Ashgate,

Setterfield, M (1997) Rapid Growth and Relative Decline, London: Macmillan.

Setterfield, M. (2010) Handbook of Alternative Theories of Economic Growth, Cheltenham: Edward Elgar.

Simandan, D. (2011) Is Engaged Pluralism the Best Way Ahead for Economic Geography? Progress in Human Geography, 35, pp. 568-572.

Soo T. K. (2005) Zipf's law for cities: a cross country investigation, Regional Science and Urban Economics 35, pp. 239-263.

Storper, M. (2013) Keys to the City: How Economics, Institutions, Social Interaction and Politics Shape Development, Princeton: Princeton University Press.

Storper, M., Kemeny, T. Makarem and Osman, T. (2014) The Economies of Cities: The Divergence of San Francisco and Los Angeles, 1970 to the Present, mimeo, Stanford Institute for Economic Policy Research.

Sturgen, N. (2014) Speech to Scotland's Business Sector, Glasgow (1 December 2014), Reported in The Herald (Scotland) http://www.heraldscotland.com/politics/scottish-politics/sturgeonlondon-brings-benefits-to-scotlands-economy.1417439283.

The Atlantic (2011) City Limits. A Conversation with Ed Glaeser, The Atlantic, February 8.

(http://www.theatlantic.com/national/archive/2011/02/city-limits-aconversation-with-edward-glaeser/70351/)

Tilley, C. (1989) Big Structures, Large Processes, Huge Comparisons, New York: Russell Sage Foundation.

Toner, P. (1999) Main Currents in Cumulative Causation: The Dynamics of Growth and Development, Basingstoke: Macmillan Press.

Wilcox, Z., Nohrova, N. and Bidgood, E. (2014) How Do Britain's Cities View London? Centre for Cities, London.

Wintour, P. (2015) George Osborne: Power to the Cities could Reverse the Thatcher Legacy, The Guardian , Monday 27 April, p. 10 
